\title{
Türkiye'de İyi ve Kötü İşler: Genç Çalışanlar Üzerinden Bir Analiz
}

Gülbin ERDEM-KARAHANOĞLU (https://orcid.org/0000-0002-7731-3991), İstanbul Medeniyet University, Turkey; gulbin.erdem@medeniyet.edu.tr

Handan KUMAŞ (https://orcid.org/0000-0002-1125-858X), Pamukkale University, Turkey; hkumas@pau.edu.tr

\section{Good and Bad Jobs in Turkey: An Analysis on Young Employees}

\begin{abstract}
Young people are at a disadvantage in terms of work and working conditions compared to adult workers in Turkey as in the rest of the world. This study analyses the quality of the jobs that young people are employed in through the "Labour Market Segmentation Theory" and assesses the factors affecting this situation. This framework divided jobs into 'good' and 'bad' jobs following the relevant theory. The 2019 TUIK Household Labour Force Survey Micro Data Set (HIAMVS) is utilized in the analysis. The young population range is a 15-29 age group, similar to ILO's "Global Employment Trends for Youth" reports. Probit model results indicate that jobs are segmented, supporting the theory. According to the findings, the socio-demographic characteristics of young people, the sector they work in, their occupation, and the region they live in significantly affect the probability of employment in a good job.
\end{abstract}
Keywords $\quad$ : Quality of Jobs, Young Employees, Segmented Labour Market Theory.

JEL Classification Codes : J42, J31, J21.

\section{$\ddot{\mathbf{O} z}$}

Dünya geneline benzer biçimde Türkiye'de de yetişkin çalışanlara göre gençler, iş ve çalışma koşulları açısından dezavantajlı durumdadır. Bu çalışmanın amacı, gençlerin çalıştıkları işlerin kalitesini "Tabakalı Işsü̈ü Piyasası Kuramı" üzerinden analiz etmek ve bir durum tespiti yapmaktır. Araştırmada, ilgili kurama uygun biçimde işler 'iyi ve kötü iş' olarak ayrılmış, analizler 2019 TÜİK Hanehalkı İşgücü Anketi Mikro Veri Seti (HİAMVS)'nden yararlanılarak yapılmıştır. Çalışmada, genç nüfus ILO'nun “Gençler için Küresel İstihdam Eğilimi Raporları” na benzer biçimde, 15-29 yaş olarak belirlenmiştir. Probit model bulguları, kuramı destekleyecek biçimde işlerin tabakalaştı̆̆ını göstermektedir. Bulgulara göre, gençlerin sosyo-demografik özellikleri, çalıştıkları sektör, meslekleri, yaşadıkları bölge iyi işte çalışma olasılığını anlamlı düzeyde etkilemektedir.

Anahtar Sözcükler $\quad$ : $\quad$ İşin Niteliği, Genç Çalışanlar, Tabakalı İşgücü Piyasası Kuramı. 


\section{Giriş}

Birleşmiş Milletler (BM), Uluslararası Çalışma Örgütü (ILO), Ekonomik Kalkınma ve İşbirliği Örgütü (OECD) ve Avrupa Birliği (AB)'nin çalışma raporlarında, uluslararası ve ulusal yazında sıklıkla gençlerin işgücü piyasasındaki eğreti çalışma biçimleri vurgulanmaktadır. Verimlilik ve ücret ilişkisini, 'işin kalitesi' açısından inceleyen çalışmalarda, işin niteliği/kalitesi ile bireysel ve toplumsal refah, büyüme ve kalkınma arasında yakın bir ilişki saptanmıştır (Kalleberg \& Vaisey, 2005: 431). Dolayısıyla, gençlerin düşük kaliteli işlerde çalışmaları, verimliliği ve ücreti düşük işlerde çalışmalarına neden olmaktadir.

İşücü piyasasında benzer verimliliğe sahip bireylerin farklı ücret alması, Neo-Klasik İktisat yaklaşımı ile emeğin verimlik farkları üzerinden arz yönlü biçimde açıklanmaktadır. Neo-Klasik İktisadın ücret dağılımını açıklamada yetersiz kalması (Taubman \& Wachter, 1986: 1183); yaklaşımın iktisat yazınında reddedilmesine (Cain, 1976), anti-tezi olarak, Kurumcu İktisadın egemen olduğu 'Tabakalı Iş̧ücü Piyasası Kuramı' (Berndt, 2014) ve Neo-Klasik İktisadın egemen olduğu 'Beşerî Sermaye Kuramı'nın (Dickens \& Lang, 1992; Bauder, 2001) gelişmesine ve ücret ile verimlilik arasındaki ilişkinin talep yönlü biçimde açıklanmasına neden olmuştur.

İktisat yazınında verimlilik ve ücret ilişkisinin farklılaşmasının veya ücretin belirlenmesinin tarihsel kökeni, Ortodoks iktisatçı, Smith'in üretimde iş bölümü ve uzmanlaşmaya bağlı farklı işlerde farklı ücret (Jastiené, 2010: 55) ve 'Telafi Edici Ücret Farklılıklarl' yaklaşımına (işçi sendikaları ve düşünsel unsurlar gibi) (Taubman \& Wachter, 1986: 1187) ${ }^{1}$, Marshall'ın 1880'lerde meslek, coğrafya ve endüstri farklılıklarına dayanarak ortaya attığı 'rekabet edemeyen piyasalar' (Marshall, 2013) ve Mill'in işgücü piyasasında kurumsal gelenek ve kurallara göre işleyen 'rekabet etmeyen gruplar'dan oluşan piyasalar (Taubman \& Wachter, 1986: 1187; Jakštienè, 2010: 55) varsayımlarına dayanmaktadır.

Ortodoks Kurama göre emeğin ücreti, bireysel özelliklerine göre belirlenmektedir. Aynı zamanda piyasadaki rekabet koşulları, gruplar arasındaki işgücü piyasasından kaynaklanan farklılıkların azalmasını ve işverenin kârını en üst düzeye çıkarmasını sağlayabilmektedir. Bu bağlamda Neo-Klasik İktisada göre, işgücü piyasasında ücrete bağlı bir tabakalaşma anormal bir durumdur (Reich et al., 1973: 359). Ancak mevcut koşullarda yeterli önlemler alınmasına rağmen, gruplar arasındaki işgücü piyasası farklılıkları ortadan kalkmamış ve Ortodoks Kuram işgücü piyasasındaki tabakalaşmayı açıklamada yetersiz kalmıştır (Reich et al., 1973: 359).

1 Adam Smith (1997: 89-94)'e göre; ücretlerin eşitlenmemesinin veya yüksek olmasinın temel nedeni işin dört koşullu ile ilgilidir. İşin ilk koşulu olan, zorluk, temizlik ve saygınlığı ne kadar çoksa; ikinci koşul işi öğrenmenin maliyeti, zaman ve çabası ne kadar çoksa; üçüncü koşul işin sürekliliği ne kadar uzunsa ve dördüncü koşul bireye duyulan güven ne kadar çoksa, ücret de o kadar çok olacaktır. Ayrıca, bir diğer koşula göre bir işte başarılı olma olasıllğı ne kadar yüksekse, o işsin kazancı o kadar yüksek olacaktır. Bu durumda, nitelikli ve niteliksiz emeğin kazancı da eşit olmayacaktır. 
Ortodoks İktisattan farklı biçimde Kurumcu İktisada göre, işgücü piyasası tabakalı bir yapıya sahiptir: Işsizlik, ayrımcılık ve gelir dağllımı sorunlarının temelinde tabakalı yapı yer almaktadır (Taubman \& Wachter, 1986: 1183). Tabakalı yap1, benzer niteliklere sahip bireylerin benzer işlerde çalışmasını ve benzer ücret almasını engellemektedir. Örneğin; bireylerin eğitim olanaklarından eşit biçimde yararlanamaması, 'işin niteliği (iyi ve kötü iş)' açısından işgücü piyasasını rekabetçi olmayan piyasalara dönüştürerek (Leontradidi, 1998), emeğin niteliğinin altında veya üzerinde ücret almasına ve ücretin de tabakalaşmasına neden olmaktadır (Fishman \& Kimhi, 2013: 2; Cain, 1976; Kumaş \& Çağlar, 2017: 56). Bu noktada işe bağlı beceri farklılıkları, bazı bireylerin neden diğerlerinden daha fazla para kazandığını açıklamaktadır (Kalleberg et al., 1981: 656).

Dünyanın pek çok ülkesinde gençler işgücü piyasasında işsizlik, ayrımcılık, sosyal dışlanma, düşük gelir grubunda yer alma ve eğitimde eşit firsatlara sahip olamama gibi nedenlerden dolayı kendi verimliliklerine göre değil, işin niteliğine göre ücret aldıkları tabakalı bir piyasada çalışabilmektedir. Bu bağlamda çalışmanın soruları; 'Tabakalı İşgücü Piyasası Kuramı'nın Türkiye'de genç çalışanlar açısından geçerli midir?' ve '15-29 yaş grubundaki gençlerin iyi veya kötü bir işte çalışma durumunu belirleyen unsurların neler olduğu'dur. Soruların yanıtı, kuramla ilgili yazınında en temel eserlerden biri olan, Peter B. Doeringer ve Michael J. Piore'nin (1970) “Internal Labor Markets and Manpower Analysis" başlıklı araştırması esas alınarak yanıtlanmaya çalışılmıştır. Bu çalışmanın amacı, kuramın 15-29 yaş arası gençler odağında incelenmesidir. Dolayısıyla, analizlerde temel bazı işgücü piyasası göstergeleri dışında, diğer yaş grupları ile karşılaştırma yapılmamıştır. Kuramın analizi TÜİK 2019 İşü̈cü İstatistikleri Mikro Veri Seti aracılığı ile yapılmıştır. Çalışma, kurama yönelik yazın incelemesi ve probit model kullanılarak elde edilen bulguları içeren iki temel bölümden oluşmaktadır. Çalışmanın yazın incelemesinde, 'Türkiye'de Tabakalı İşgücü Piyasası Kuramı'nı genç çalışanlar (15-29 yaş) açısından inceleyen bir esere rastlanılmamıştır. Dolayısıyla bu araştırmanın amacı, ilgili yazına genç işgücünün işgücü piyasasındaki konumlarını açığa çıkarmaya yönelik farklı bakış açısı ile katkı sağlamaktır.

\section{Yazın İncelemesi}

Ücrete bağlı işgücü piyasasında ikili yapı, Averitt'in (1968) “Ikili Ekonomi: Amerikan Sanayi Yapısının Dinamikleri" eseri ve 1970'li yılların başında Doeringer ve Piore'nin (1970) "İçsel İşgücü Piyasaları: Insan Gücü Analizi” eseri ile tartışılmaya başlanmış ve 'İkili İsgü̈cü Piyasası' kavramı (Hudson, 2007: 286) diğer bir ifade ile 'Tabakalı İsgü̈ü Piyasası' kavramı iktisat yazınında yerini almıştır. Reich et al. (1973; 1975) ise 'İçsel Işsgücü Piyasası'nı düzenlilik ve 'Dışsal İsgücü Piyasası'nı düzensizlik ile betimleyerek kuramı genişletmiştir. Kalleberg (1981, 2003, 2009, 2012) tarafindan yapılan çok sayıdaki kuramsal ve deneysel çalışmalar 'iyi iş’ ve 'kötü iş’ ayrımını belirginleştirerek evrimleştirmiştir.

Tabakalı işgücü piyasası 'içsel ve Dışsal Piyasa (internal-external market) ve Birincil ve Íkincil Piyasa (primary-secondary sector) ve İyi ve Kötü İş (good-bad job)’ biçiminde sınıflandırılmaktadır. İkili tabakalı yapı, birincil ve ikincil piyasa veya içsel ve dışsal 
piyasayı içermektedir. Doringer ve Piore (1970: 25), içsel işgücü piyasalarını beceri özgüllüğü; işbaşı eğitimi ve geleneksel kurallar gibi geleneksel iktisat kuramında öngörülemeyen bir dizi faktörle açıklamaktadır. Beceri özgüllüğü, o işi yapmanın ayrı bir bilgi-tecrübe gerektirmesini ifade etmektedir (Doeringer \& Piore, 1970: 26).

İçsel piyasada işin gerektirdiği bilgi, beceri, donanım, yetenek ve/veya nitelik ne kadar yüksekse, ücret o kadar yüksektir. Yüksek ücretli işler 'iyi işlerdir' ve bu işler, birincil piyasa/içsel piyasada (firma piyasası veya kariyer piyasası) bulunmaktadır. İçsel işgücü piyasalarında ücret ve emeğin üretim sürecindeki yeri rekabetten/piyasadan bağımsız biçimde, işletmenin yönetsel kurallarına (Doeringer \& Piore, 1970: 8-9, 25) ve verimlilikten daha çok gelenek gibi faktörlere göre (Wachter, 1974: 639) belirlenmektedir. İçsel işgücü piyasası çalışanlarına 'iyi işi' yani; yüksek ücreti düzenli geliri, uzun süreli iş ilişkisini, çalışma garantisini, iş güvencesini, iyi çalışma koşullarını, iş eğitimini, firma ve sektörde hareketliliği, kariyer fırsatını, eşitlik ve kararlara katılımı, işbaşı eğitimini, sendikalaşma, avans ve teşvik olanağını, yönetimde adaleti, sağlığa daha fazla erişimi, sigorta ve emeklilik yardımlarını ve iş güvenliğini sağlayan bir piyasadır (Doeringer \& Piore, 1970: 25, 272; Daw \& Hardie, 2012: 1182; Kumaş \& Çağlar, 2017: 56). Bu piyasada başarı ödüllendirilmekte ve kişi genellikle kendi becerisi ile işe alınmaktadır (Reich et al., 1973: 360). Sürekliliği olan ve eğitimli işgücüne sahip olmak isteyen işverenler, çalışanlarına kariyer olanağı sunarak onların daha uzun süre işte kalmalarına yardımcı olmaktadır (Smith \& Noma, 1985: 149). Aynı zamanda, içsel piyasaya dışsal piyasadan geçiş neredeyse kapalıdır ve iyi işleri barındıran bu piyasadaki firmalarda çalışma edilen bireyler, piyasanın etki ve rekabetinden korunmaktadır (Eriksson \& Werwatz, 2005: 2). Dolayısıyla, ücret farklılıkları esas olarak işlerin özelliklerinden kaynaklanmaktadır (McNabb, 1987: 259).

İçsel işgücü piyasasında yer alan firmalarda üretim genelde sermaye yoğun tekniğe, makineye ve yüksek teknolojiye dayanmaktadır. İçsel işgücü piyasası içerisinde yer alan işler, yönetsel işler (profesyonel ve yönetici işleri) ve doğrudan üretim sürecindeki mavi yakalılara yönelik işlerden oluşmakta (Doeringer \& Piore, 1970: 10-11, 25; Jastiené, 2010: 56) ve işler üst veya alt kademe olarak sınıflandırılmaktadır. Bu işlerde ücretler, özel anlaşmalarla pazarlık edilmektedir (Anderson et al., 1987: 573). İçsel piyasada giriş pozisyonundaki işler için niteliksiz veya zanaat odaklı becerilere sahip bireyler seçilmektedir (Wachter, 1974: 643).

İkincil/dışsal piyasada işlerin niteliğine paralel biçimde azınlık işçileri, gençler ve çocuklar gibi (Doeringer \& Piore, 1970: 273-274; Reich et al., 1973: 360; Wachter, 1974: 651) dezavantajlı gruplar çalışmaktadır (Doeringer \& Piore, 1970: 272). Ayrımcılık ve işsizlik, ikincil piyasada eksik çalışmaya neden olmaktadır (Doeringer \& Piore, 1970: 165, 301; Piore, 1972; Wachter, 1974: 639; Hudson, 2007: 298; Anderson et al., 1987: 573).

İkincil piyasa/dışsal piyasada, ücret ve çalışma koşulları, içsel piyasanın tersine, piyasadaki rekabet koşullarına göre belirlenmektedir (Anderson et al., 1987: 573). Dolayısıyla bu piyasa kötü işleri barındırmaktadır. Kötü iş; düşük ücretli, iş güvencesinin olmadığı, kariyer fırsatının çok sınırlı olduğu ya da olmadığı, çalışma koşullarının kötü ve 
yüksek işgücü devrinin olduğu, sendikalaşmanın ve yan ödemelerin olmadığı, sosyal hakların çok az elde edildiği, kısa süreli ve genellikle keyfi ve kaprisli bir yönetimin olduğu işlerdir (Doeringer \& Piore, 1970; Hudson, 2007: 272; Lazear \& Oyer, 2004: 531; Piore, 1972; Hudson, 2007: 288; Dickens \& Lang 1988: 132; Reich et al., 1973; Wachter, 1974; Osterman, 1975; Horn, 1980; Anselme \& Weisz, 1985; Rebitzer \& Robinson, 1991; Lamotte \& Zubiri-Rey, 2008; Kalleberg et al., 2000). İşü̈cü piyasasındaki kötü/ikincil işler rutinleşmiş nitelik taşırken, iyi/birincil işler yaratıcılık gerektirmektedir (Reich et al., 1973: 360).

Daw ve Hardie'nin 1957 Wisconsin Longitudinal Study (WLS) veri tabanını kullanarak ABD'de yaptıkları araştırmasında birincil sektör, medyan üzerinde ücreti, çeşitli çıkarları ve en yüksek iş güvencesini sağlayan işler olarak tanımlanmıştır (2012: 1184). Diğer yandan, ikincil piyasadaki işler, çoğunlukla yarı zamanlıdır ve güvencesizdir (Daw \& Hardie, 2012: 1182).

Dışsal piyasadaki firmaların çoğu hizmet, toptan ve perakende ticaret sektörlerinde faaliyet göstermektedir (Wachter, 1974: 651). İkincil piyasada (veya piyasadaki firmalarda) bireylerin yoğun bir denetim ve baskı altında olması, işbaşı eğitimi ve kariyer gelişiminin sınırlı olması, (Loveridge \& Mok, 1980), çalışanların aynı işyerinde uzun süreli ya da yüksek verimlilikle çalışma konusundaki güdülenmelerini düşürmektedir. Oysa birincil piyasada çalışanlar, sağladıkları çıkarlar karşılığında (sağlık yararları, sigorta poliçeleri, emekli aylığı ücretleri ve iş güvenliği gibi), kendilerini işverene ispatlamaya ve hizmet etmeye güdülemiştir (Doeringer \& Piore, 1970: 165, 301; Piore, 1972; Wachter, 1974: 639; Hudson, 2007: 298; Kalleberg et al., 2009: 101, 107; Kalleberg, 2012: 436). Ayrica birincil piyasaya göre ikincil piyasada, daha yüksek düzeyde işe geç kalma ve devamsızlık oranları ve işten çıkarmalar görülmektedir (Wachter, 1974: 651). Tersi biçimde, içsel işgücü piyasasında kıdem tazminatı gibi sosyal hakların bulunması ve firmaların kendi işe alma kurallarının olması, işten çıkarmanın maliyetini yükseltmektedir. Bu nedenle iyi işlerin olduğu içsel işgücü piyasası, piyasa koşullarından ve ekonomik krizlerden çok daha az etkilenmektedir. (Bosanquet, 1987).

İyi işler için eğitim, genellikle bir pasaport niteliğindedir. Eğitimli ve nitelikli işçiler, niteliksiz işçilerden daha üretken olma eğilimindedirler. Ancak, işgücü piyasası tabakalaşmış ise eğitim tek başına iyi işlere erişmede yetersiz kalmaktadır (Pages \& Stampini, 2009: 387). Bununla birlikte, McNabb'in (1987) araştırmasında eğitimin, birincil piyasada kalmak için tek başına yeterli olmadığı, birincil piyasanın sosyal değer ve yapısına da uyum sağlamanın önemli olduğu ve iyi eğitim sayesinde içsel/birincil piyasada çalışan kişilerin, zamanla ikincil piyasaya geçtikleri/kaydıkları tespit edilmiştir.

Ashton et al. (1990), 1980'lerde Birleşik Krallıkta yaptıkları araştırmada tabakalaşmanın işgücü piyasasında yarattığı baskının gençlerin; çalışacakları mesleklerin değişimine neden olduğunu ve her bir tabakanın farklı kariyer fırsatı, işsizlik tehdidi ve kendine özgü giriş ve çıkış modeli sunmasının, kişisel özelliklerden bağımsız olarak, piyasada kalma şanslarını kısıtladığını tespit etmiştir. 
Ashton et al. (1990) benzer biçimde, López-Roldán ve Fachelli $(2020$ : 867, 869) ve López-Roldán et al. (2021: 90, 95), tabakalı işgücü piyasasını İspanya ve Arjantin'de faktör ve küme analizi yöntemleri ile karşılaştırdıkları çalışmalarda da kısa süreli, düşük beceri gerektiren, kayıt dışı ve çoğunlukla yarı zamanlı, iş güvencesinin sağlanmadığı, en düşük ücret düzeyinin olduğu işlerde, özellikle diğer hizmetler, inşaat ve perakende sektörlerinde (ve ayrıca İspanya örneğinde birincil sektörde) ve küçük ölçekli ve özel sektördeki işletmelerde çoğunlukla gençlerin çalıştığı gözlenmiştir.

López-Roldán ve Fachelli (2020: 867, 869) ve López-Roldán et al. (2021)'nin çalışmalarındaki sektörlere benzer biçimde Norveç'te 1995 yılında 18-24 yaş grubunda tabakalı yapının çok değişkenli analizler ile 2000 genç üzerinde analiz edildiği araştırmada, tekrarlayan işsizlik yaşayan erkeklerin inşaat, süreç endüstrisi ve ulaşım gibi düşük nitelik gerektiren işlerinde kadınların ise satış, perakende ve nitelik gerektirmeyen hizmet işlerinde yoğunlaştığı ve cinsiyete göre mesleki tabakalaşmanın, iş eğitimi ve sürekli işte çalışma durumunu belirlediği görülmüştür (Stavik \& Hammer, 2000).

Lukac et al. (2019), on bir Avrupa ülkesini karşılaştırdıkları araştırmada da gençlerin kötü olarak nitelenebilecek işlerde çalıştıkları gözlenmiştir: İşgücü piyasasındaki tabakalaşmanın işlerin standart ve standart olmayan (ücret, çalışma saatleri ve denetim açısından) tanımlamalar ile ölçüldüğü araştırmada, gençlerin dezavantajlı grup olarak standart olmayan ve daha düşük gelir getiren işlerde çalıştıkları gözlenmiştir (Lukac et al., 2019).

Tabakalı İşgücü Piyasası Kuramı ILO tarafından da benimsenmiş ve işgücü piyasasının tabakalaşması olgusu geliştirilmiştir. ILO'ya göre İşgücü piyasasında tabakalaşma, son yıllarda tüm dünyada gözlemlenebilmekte ve piyasalar farklı özelliklere ve davranış kurallarına göre alt pazarlara veya bölümlere ayrışmaktadır. Tabakalaşma, sözleşmeye dayalı düzenlemeler (iş sözleşmelerinin sürekli/geçici doğası boyunca bölünmesi) gibi işgücü piyasası kurumlarının özelliklerinden, uygulama eksikliğinden (resmi/resmi olmayan bölünme) ve işgücünün özelliklerinden (göçmen ve göçmen olmayan işçiler gibi) kaynaklanabilmektedir (ILO, 2021a). ILO "2020 Gençlik için Küresel İstihdam Ĕgilimleri" raporunda, işgücü piyasalarının küresel boyutta yaş ve cinsiyete göre tabakalaştığı ve teknolojik değişimin etkilerinin, yetişkin çalışanlara göre gençlerde, eşitsiz dağılıma ve farklı sonuçlara neden olduğu vurgulanmaktadır (ILO, 2020: 59, 106-123). ILO raporuna göre (2020: 109), çoğu ülkede yetişkinlerle karşılaştırıldığında gençler, düzensiz, standart olmayan ve eğreti işlerde ${ }^{2}$ çalışmalarından dolayı daha fazla ücret eşitsizliği yaşamaktadır ancak küresel ekonomik ve mali krizler yaşa bağlı ücret makasını daraltmıştır.

2 ILO (2016:18) 'ya göre eğreti istihdam, iş güvencesizliğini, yoksulluk düzeyinde veya altında düşük ve süreksiz bir ücreti, yüksek riskte iş kaybını, en az düzeyde sosyal korumayı ve iş hukuku düzenlemelerini, çalışma koşullarında en düşük düzeyde kontrolü, belirsiz bir çalışma süresini, korumasız ve ayrımcilığa açık işlerde çalışmayı ifade etmektedir. 
Çalışma sırasında ‘Tabakalı İşgücü Piyasası Kuramı'nı Türkiye'de doğrudan gençler için araştıran bir çalışmaya rastlanılmamıştır. Bununla birlikte, kurama göre işgücü piyasasının analizinin yapıldığı az sayıdaki çalışmada gençlerin genellikle kötü işlerde çalıştıkları bulgularına ulaşılmıştır. İnşaat sektöründe Karaalp-Orhan ve Aksoylu'nun nitel yöntemle 41 kişi ile görüşerek yaptıkları çalışmada, kurumsal firmalarda genç ve yetişkinler arasında belirgin bir ücret farklılıkları ve dışsal piyasada çalışanların içsel piyasadakiler ile aynı nitelikte olmalarına rağmen düşük ücretle çalıştıkları (Karalp-Orhan \& Aksoylu, 2018: 12-13) tespit edilmiştir. Şenel'in inşaat sektörü özelinde, TÜİK 2016 İşgücü Anketi Mikro Veri Seti ve Denizli ilindeki nitel araştırmada (16 kişi), genç ve 50 yaş üzeri çalışanların iyi işte çalışma olasılıklarının, diğer yaş gruplarına göre çok daha düşük olduğu gözlenmiştir (Şenel, 2021: 16, 34-35).

Aydın (2009: 41, 47, 75): TÜİK İşgücü Anketi Mikro Veri Seti 1988-2006 dönemini içeren araştırmasında, enformel çalışmanın büyük bir bölümünün gençlerden oluştuğu sonucuna ulaşmıştır. Ayrıca kamu sektörü ve kurumsallaşmış büyük ölçekli firmaları, düzenli iş-gelir ve iş güvencesi ve iyi çalışma koşulları, kariyer firsatı ve sendikalaşma olanağı sağlamasından dolayı içsel piyasa; sendikalaşma olanağı sunmaması, daha az iş güvencesini sağlaması ve piyasanın rekabetine açık olmasından dolayı kamu sektöründe sözleşmeli ve geçici çalışanları, taşeron çalışanlarını, özel sektördeki küçük işletmelerde çalışanları dışsal piyasa çalışanları olarak nitelemiştir.

Kumaş vd. (2014: 367, 368, 370) işletme ölçeği odağında kuramın geçerliliğini test ettikleri ve TÜİK 2011 İşü̈ü Anketi Mikro Veri Seti aracılığı ile yaptıkları İkili Lojistik Regresyon analizlerinde, ücretli, maaşlı çalışan 15-19 yaş grubu; işletme ölçeği, meslek ve sektör değişkenlerine göre en olumsuz koşullara sahip grup yaş grubu olarak tespit edilmiştir. Kumaş ve Çağlar'ın (2017: 77) TÜİK 2015 İşgücü Anketi Mikro Veri Seti’nden yararlanarak ve farklı yaklaşımlarla yaptıkları İkili Lojistik Regresyon analizlerinde; genç (15-24 yaş grubundakilerin \%93,2'si kötü işte çalışmaktadır) ve 50 yaş ve üzerinde olmanın,

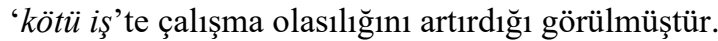

Türkiye'de Covid-19'un etkilerinin 'ne istihdamda ne de eğitimde olan' yerli (1000 kişi) ve mülteci (250 kişi) gençler üzerinde etkisinin nicel ve nitel yöntemlerle araştırıldığ 1 ILO raporunda (2021b), her iki grubun da uzun sürelerle, düzensiz çalışma koşulları ve düşük ücretlerle çalıştıkları ve işletmelerden daha fazla beceri geliştirme firsatı ve daha hijyenik çalışma ortamı sağlanması konularında beklenti içinde oldukları ifade edilmiştir.

Yazın incelemesinin sonucunda hem uluslararası ve hem de ulusal araştırmalarda benzer bulgulara ulaşıldığı görülmüştür. Bulgulara göre gençler çoğunlukla ücret düzeyi, işin gerektirdiği nitelik, kariyer fursatı, iş güvencesi ve kayıtlı çalışma ve sektör açısından kötü iş olarak nitelenebilecek işlerde çalışmaktadır. 


\section{Yöntem}

\subsection{Veri Seti, İlgili Özet İstatistiki Bilgiler ve Kısıtlar}

Çalışmada temel amaç 15-29 yaş grubu gençlerin çalıştıkları işlerin kalitesini incelemektir. Bu kapsamda TÜIK 2019 HİAMVS kullanılmıştır. HİAMVS, 15 yaş ve üzeri kişiler ile ilgili detaylı demografik ve mevcut dönemin işgücü bilgileri ile bir önceki dönemin işgücü bilgilerini içermektedir. Çalışmanın kapsamının 15-29 yaş grubu olmasının nedeni, ILO'nun “Küresel Genç Nüfus İstihdamı Raporları"nda gençlerin, 15-29 yaş grubu olarak belirlenmesidir (ILO, 2017, 2020).

Tablo: 1

Temel İşgücü İstatistikleri

\begin{tabular}{|c|c|c|c|c|c|c|}
\hline \multirow{3}{*}{ Ferdin İşgücü Durumu } & \multicolumn{3}{|c|}{$15-64$} & \multicolumn{3}{|c|}{ 15-29 } \\
\hline & \multicolumn{3}{|c|}{ Cinsiyet } & \multicolumn{3}{|c|}{ Cinsiyet } \\
\hline & Erkek & Kadın & Toplam & Erkek & Kadın & Toplam \\
\hline İşgücü (Bin) & $21.215,04$ & $10.456,60$ & $31.671,60$ & 6.042 & $3.399,09$ & 9.441 .00 \\
\hline İşgücüne Katılma Oranı (\%) & 78,16 & 38,72 & 58,48 & 67,73 & 38,62 & 53,27 \\
\hline İstihdam (Bin) & 18.531 & $8.698,58$ & $27.229,70$ & $4.861,85$ & $2.491,69$ & $7.353,54$ \\
\hline İstihdam Oranı (\%) & 68,27 & 32,21 & 50,28 & 54,5 & 28,31 & 41,49 \\
\hline İşsiz (Bin) & $2.683,94$ & $1.758,00$ & $4.441,94$ & $1.180,06$ & 907,395 & $2.087,46$ \\
\hline İşsizlik Oranı (\%) & 12,65 & 16,81 & 14,02 & 19,53 & 26,7 & 22,11 \\
\hline İşgücüne Dahil Olmayanlar (Bin) & $5.930,14$ & $16.552,40$ & $22.482,50$ & $2.878,70$ & $5.403,76$ & $8.282,46$ \\
\hline İşgücüne Dahil Olmayanlar (\%) & 21,85 & 61,28 & 41,52 & 31,87 & 62,7 & 47,14 \\
\hline Çalışma Çağındaki Nüfus (Bin) & $27.145,20$ & $27.008,90$ & $54.154,10$ & $8.920,60$ & $8.802,85$ & $17.723,50$ \\
\hline
\end{tabular}

Kaynak: 2019 HIAMVS.

Veri Seti'ne göre 30 yaş ve üzeri yetişkinlerde işgücüne katılma oranı $\% 52,82$; çalışma oranı \%47,38; işsizlik oranı ise \%10,31 iken, 15-29 yaş arası gençlerde ise sırasıyla bu oranlar \%53,27; \%41,49 ve \%22,11 biçimindedir. Genç nüfus ile çalışma çağındaki nüfus temel işgücü göstergeleri açısından karşılaştırıldığında, genç olmanın daha fazla işsizlik, daha az çalışma ve daha çok işgücünde olmama riski taşıdığı görülmektedir. Üstelik genç kadın olmak, işgücü piyasasındaki dezavantajlı durumu daha da pekiştirmektedir (Tablo 1). Genç kadın işsizliği, genel işsizliğin yaklaşık 1,2 katı daha fazladır. İşgücündeki tüm bu göstergeler kuramın ayrımcılığın tabakalı yapıya neden olduğu varsayımını destekler niteliktedir. Aynı zamanda işsizlik oranı yüksek ve gelir düzeyi düşük grupta yer almak tabakalaşmayı belirginleştirmektedir.

İşgücü piyasasında dezavantajlı gruplar, kuramın sınıflamasına göre dışsal piyasada veya ikincil sektörde yani kötü işlerde çalışmaktadırlar. Bu bağlamda çalışmada kurama uygun biçimde işler iyi ve kötü olarak gruplandırılmış ve Türkiye işgücü piyasasının yapısına göre mikro veri setinden yararlanılarak iyi ve kötü işin özellikleri belirlenmiştir. İyi işler ortalama ücret düzeyinin üzerinde bir ücreti, düzenli, sürekli, kayıtll, çalışma biçiminin tam zamanlı olduğu ve haftalık çalışma süresinin 31-45 saat olduğu işleri kapsamaktadır. Kötü iş ise iyi işin özelliklerinin en az bir tanesinin sağlanmadığ işlerdir.

Tabakalı İşücü Piyasası Kuramında 'iyi veya kötü iş' in gruplandırılmasında çalışma süresi bir özellik olarak tanımlanmamıştır. Bu durumda, çalışma süresi ile ücret düzeyi arasındaki anlamlı ilişki olasılığı, iyi işin tanımlanmasında araştırmacıya 'siyah-beyaz veya 
gri alanlar' üzerinden analiz yapma firsatı sunmaktadır ${ }^{3}$. Aynı zamanda çalışmada, tam zamanlı çalışmanın iyi iş olarak belirlenmesinde, ILO'nun standart çalışmayı tam zamanlı, standart dışı çalışmayı ise yarı zamanlı çalışma (ILO, 2016: 18) ve 4857 Sayılı İş Yasası'nda tipik çalışmanın tam zamanlı çalışma olarak değerlendirilmesi yaklaşımlarından ve yazın bulgularından hareket edilmiştir. ILO'ya göre (2016: 138) standart olan ve olmayan çalışmanın bir arada bulunması, işgücü piyasasında tabakalaşmaya veya ikili yapıya yol açmaktadır. Bu durum, gençlerin düşük kaliteli işlerde savunmasız biçimde (ILO, 2016: 143) ve tam zamanlı çalışanlarla karşılaştırıldığında iş güvencesinin ve sosyal güvenlik haklarının kırılgan olduğu işlerde gönüllü veya gönülsüz olarak çalışmasına neden olabilmektedir (ILO, 2016: 226).

Modelde veri seti yapısından dolayı, işin niteliğini belirleyen tüm özellikler analize dahil edilememiştir. Kuramda iyi işin niteliğini belirleyen beceri özgüllüğü, verimlilik, sendikalaşma, işbaşı eğitimi, kariyer fırsatları, çalışma kurallarının yönetiminde eşitlik ve yasalara uygunluk ve iyi çalışma koşulları gibi tüm özellikler, veri setinde yer almadığı için bu unsurlar modelin dışında bırakılmıştır. HİAMVS'lerindeki değişkenler, işgücü arz yönünü yansıtan değişkenlerle sınırlıdır. Çalışmanın bir diğer kısıtı ise mikro veri setinde gelir bilgisinin sadece ücretli, maaşlı ve yevmiyeli (ÜMY) çalışanlara sorulmasından dolayı, kendi hesabına ve işveren olarak çalışan gençlerin çalışma kapsamına alınamamasıdır. 1529 yaş arası ÜMY'lerin ağırlıklandırılmış örneklem sayısı, 5 milyon 874 bin kişi, ağırlıklandırılmamış örneklem sayısı ise 28.542 kişidir.

15-29 yaş arası çalışanların büyük çoğunluğunun işteki durumu, ÜMY'dir (\%80). 2019 y1lı için 15-64 yaş grubu ÜMY'lerin “Geçen ay içinde esas işinizden elde ettiğiniz dönemsel olarak elde edilen ikramiye, prim vb. gelirler dahil toplam net nakdi gelir"e göre ortalama gelir düzeyi, yaklaşı 2.749 TL'dir. Tüm yaş gruplarındaki erkeklerde söz konusu gelir, 2.833 TL iken, kadınlarda 2.563 TL'dir (Tablo 2). Farklı bir yaş grubundaki 30-64 yaş ÜMY'ler için geçen ay elde edilen net ortalama gelir, 2.993 TL; erkeklerde 3.096 TL, kadınlarda 2.755 TL'dir. Oysa 15-29 yaş grubundaki ÜMY'ler için geçen ay elde edilen net ortalama gelir hem kadınlar hem de erkeklerde bu rakamların çok altındadır (Tablo 2). Bulgular, yaş küçüldükçe cinsiyete dayalı ortalama ücret farklılığının azaldığını, yaş ilerledikçe farkın kadınların aleyhine artığını göstermektedir.

İyi işin bir diğer unsuru olan tam zamanlı çalışma biçimi, 15-29 yaş grubunda \%88,5'tir; haftalık çalışma süresi ise ortalama, 48.3 saattir. Bu süre, 4857 sayılı İş Yasası'nın 63. maddesi ile 'genel haftalık çalışma süresi en çok 45 saattir' biçiminde düzenlenmiş çalışma süresi sınırını aşmaktadır. Veri setine göre genç çalışanların \%53’ü, haftada 45 saatin üzerinde çalışmaktadır. Gençlerin \%11,5’i yarı zamanlı çalışmaktadır. Ancak çalışma

\footnotetext{
Çalışmada 'iş’in kalitesini belirleyen özellikler, 'İkili İşücü Piyasası' kuramcılarından ve bu çalışmanın dayandiğl temel eserin yazarlarından biri olan Michael Piore ile 01.03.2017 tarihinde yapılan görüşmeden sonra oluşturulmuştur. Kuramda, ücret çalışma süresinden bağımsız biçimde ele alınmıştır. Bu noktada çalışmada, mikro veri setinde yer alan verilerle işin kalitesi belirlenebilmiş ve çalışma süreleri açısından da kuramın geçerliliği incelenmiştir.
} 
biçimi yarı zamanlı olan gençlerin yarısından fazlası ilgili yasaya aykırı biçimde fazla çalışma yapmaktadır. Türkiye'de yarı zamanlı çalışan genç kadınların oranı erkeklerden yaklaşık iki kat daha fazladır (Tablo 2).

Tablo: 2

'İş’in Özelliklerinin Yaş Grubu ve Cinsiyete Göre Dağılımı (\%)

\begin{tabular}{|c|c|c|c|c|c|c|}
\hline & \multicolumn{3}{|c|}{ 15-64 } & \multicolumn{3}{|c|}{$15-29$} \\
\hline & \multicolumn{3}{|c|}{ Cinsiyet } & \multicolumn{3}{|c|}{ Cinsiyet } \\
\hline & Erkek & Kadın & Toplam & Erkek & Kadın & Toplam \\
\hline \multicolumn{7}{|l|}{ Esas İșteki Durum (\%) } \\
\hline ÜMY & 71,09 & 67,83 & 70.05 & 80.14 & 79.37 & 79.88 \\
\hline İşveren & 5,81 & 1,45 & 4.41 & 1.87 & 0.55 & 1.42 \\
\hline Kendi Hesabına & 1,70 & 8,72 & 15.51 & 6.06 & 3.73 & 5.27 \\
\hline Ücretsiz Aile İşçisi & 4,41 & 22,00 & 10.03 & 11.93 & 16.35 & 13.43 \\
\hline \multicolumn{7}{|c|}{ Esas İşten Elde Edilen Net Gelir (Geçen Ay) } \\
\hline Ortalama Ücret (Ö̈) (Bin TL) & 2.833 & 2.563 & 2.749 & 2.121 & 2.135 & 2.131 \\
\hline OÜ'nün üstünde Çalışanlar (\%) & 0,72 & 0,28 & 0,39 & 0,66 & 0,34 & 0,24 \\
\hline OÜ'nün altında Çalışanlar (\%) & 0,67 & 0,33 & 0,61 & 0,66 & 0,34 & 0,76 \\
\hline \multicolumn{7}{|l|}{ Haftalık Çalışma Saati (\%) } \\
\hline 30 Saate Kadar & 12,14 & 25,97 & 16,53 & 14,06 & 24,94 & 17,70 \\
\hline 31-45 Saat Aras1 & 32,72 & 39,99 & 35,03 & 26,43 & 35,18 & 29,36 \\
\hline 45 Saatin Üzeri & 55,13 & 34,04 & 48,43 & 59,51 & 39,88 & 52,94 \\
\hline \multicolumn{7}{|l|}{ Çalışma Biçimi (\%) } \\
\hline Yarı Zamanlı & 6,60 & 17,03 & 9,93 & 8,83 & 16,65 & 11,48 \\
\hline Tam Zamanlı & 93,4 & 82,97 & 90,07 & 91,17 & 83,35 & 88,52 \\
\hline \multicolumn{7}{|l|}{ İşyerinin Durumu (\%) } \\
\hline Tarla/Bahçe & 12,84 & 24,46 & 16,46 & 11,3 & 17,29 & 13,32 \\
\hline Düzenli İşyeri & 79,04 & 67,53 & 75,45 & 82,63 & 79,12 & 81,45 \\
\hline Pazar Yeri & 0,69 & 0,32 & 0,57 & 0,70 & 0,10 & 0,50 \\
\hline Seyyar/Sabit Olmayan İşyeri & 7,00 & 0,61 & 5,00 & 5,04 & 0,36 & 3,47 \\
\hline Evde & 0,44 & 7,07 & 2,51 & 0,33 & 3,13 & 1,27 \\
\hline \multicolumn{7}{|l|}{ SGK'ya Kayıtlılık Durumu (\%) } \\
\hline Evet & 71,08 & 59,23 & 67,29 & 64,94 & 67,49 & 65,80 \\
\hline Hayır & 28,92 & 40,77 & 32,71 & 35,06 & 32,51 & 34,20 \\
\hline \multicolumn{7}{|c|}{ İşyerinde Süreklilik Durumu (\%) } \\
\hline Sürekli iş & 88,17 & 89,07 & 88,45 & 82,89 & 84,03 & 83,27 \\
\hline Geçici iş & 11,83 & 10,93 & 11,55 & 17,11 & 15,97 & 16.73 \\
\hline
\end{tabular}

Kaynak: 2019 HIAMVS.

15-29 yaş grubunun çoğunluğu $(\% 81,45)$ iyi işin bir diğer özelliği olan 'düzenli işler'de çalışmaktadır. 15-64 yaş grubu için söz konusu oran, \%75,45 ile daha düşük düzeydedir (Tablo 2).

ILO (2020: 39) "2020 Gençlik için Küresel Istihdam Eğilimleri” raporuna göre, dünyada 15-29 yaş grubundaki gençlerin dörtte üçünden fazlası kötü işin özelliklerini barındıran ve tamamıyla kayıt dışı çalışmayı ve süreksiz bir işte çalışmayı içeren enformel sektörde çalışmaktadır. Diğer yandan TÜIKK Mikro Veri Setine göre ise 15-29 yaş grubunun \%66's1 'kayıtlı' bir işte ve yaklaşık \%83'ü 'sürekli' bir işte çalışmaktadır (Tablo 2). Veri setine göre kayıt dışı çalışan gençlerin \%59’u, süreklilik gösteren bir işte çalışmaktadır.

Tablo 3, çalışmada kullanılan tüm değişkenlerin özet istatistik bilgilerini içermektedir. Çalışmada 15-29 yaş arası gençlerin iyi ve kötü işte çalışma durumları bağımlı değişken olarak alınmıştır. İşin kalitesinin analizinde, bireyin sosyo-demografik özellikleri, sektör, işletme ölçeği ve meslek grubu modelin açıklayıcı değişkenleri olarak belirlenmiştir. Analizde temel olarak, iyi işin özelliklerinin en az olduğu/görüldüğü grup referans olarak 
Erdem-Karahanoğlu, G. \& H. Kumaş (2022), “Türkiye'de İyi ve Kötü İşler:

Genç Çalışanlar Üzerinden Bir Analiz”, Sosyoekonomi, 30(51), 427-447.

alınmıştır. Analizde ilk bağımsız değişken olan yaş, 15-29 yaş için beş yıllık aralıklar biçiminde gruplandırılmış, bu kategoriler kukla değişkenlere dönüştürülerek, en genç yaş aralığı (15-19 yaş) referans olarak alınmıştır.

Tablo: 3

\section{Özet İstatistiki Tablo}

\begin{tabular}{|c|c|c|c|c|c|c|c|}
\hline & \multirow[b]{2}{*}{ Değişkenler } & \multicolumn{2}{|c|}{ Toplam } & \multicolumn{2}{|c|}{ Erkek } & \multicolumn{2}{|c|}{ Kadın } \\
\hline & & Ort. & $\begin{array}{c}\text { Std. } \\
\text { Sapma }\end{array}$ & Ort. & $\begin{array}{c}\text { Std. } \\
\text { Sapma }\end{array}$ & Ort. & $\begin{array}{c}\text { Std. } \\
\text { Sapma }\end{array}$ \\
\hline \multirow{4}{*}{ Yaş Grubu } & İyi İş & 0,348 & 0,476 & 0,349 & 0,477 & 0,346 & 0,476 \\
\hline & $15-19$ & 0,170 & 0,376 & 0,184 & 0,388 & 0,144 & 0,351 \\
\hline & $20-24$ & 0,343 & 0,475 & 0,329 & 0,470 & 0,370 & 0,483 \\
\hline & $25-29$ & 0,487 & 0,500 & 0,487 & 0,500 & 0,486 & 0,500 \\
\hline \multirow{2}{*}{ Cinsiyet } & Erkek & 0,663 & 0,473 & & & & \\
\hline & Kadın & 0,337 & 0,473 & & & & \\
\hline \multirow{2}{*}{ Medeni Durum } & Evli & 0,263 & 0,440 & 0,262 & 0,440 & 0,264 & 0,441 \\
\hline & Evli Değil & 0,737 & 0,440 & 0,738 & 0,440 & 0,736 & 0,441 \\
\hline \multirow{12}{*}{ Bölge } & İstanbul & 0,269 & 0,443 & 0,257 & 0,437 & 0,293 & 0,455 \\
\hline & Bat1 Marmara & 0,038 & 0,192 & 0,038 & 0,191 & 0,039 & 0,194 \\
\hline & Ege & 0,121 & 0,326 & 0,117 & 0,322 & 0,129 & 0,335 \\
\hline & Doğu Marmara & 0,107 & 0,309 & 0,102 & 0,303 & 0,115 & 0,319 \\
\hline & Batı Anadolu & 0,098 & 0,297 & 0,102 & 0,303 & 0,089 & 0,285 \\
\hline & Akdeniz & 0,113 & 0,317 & 0,114 & 0,318 & 0,113 & 0,316 \\
\hline & Orta Anadolu & 0,041 & 0,198 & 0,045 & 0,207 & 0,033 & 0,179 \\
\hline & Batı Karadeniz* (Ref. Grup) & 0,039 & 0,193 & 0,038 & 0,191 & 0,040 & 0,197 \\
\hline & Doğu Karadeniz* (Ref. Grup) & 0,022 & 0,145 & 0,022 & 0,147 & 0,021 & 0,142 \\
\hline & Kuzeydoğu Anadolu & 0,018 & 0,134 & 0,020 & 0,142 & 0,014 & 0,118 \\
\hline & Ortadoğu Anadolu & 0,038 & 0,192 & 0,042 & 0,200 & 0,031 & 0,174 \\
\hline & Güneydoğu Anadolu & 0,096 & 0,295 & 0,103 & 0,304 & 0,083 & 0,276 \\
\hline \multirow{6}{*}{ Eğitim Düzeyi } & Lise Öncesi (Ref. Grup) & 0,403 & 0,491 & 0,476 & 0,500 & 0,259 & 0,438 \\
\hline & Genel Lise & 0,108 & 0,311 & 0,109 & 0,311 & 0,108 & 0,310 \\
\hline & Mesleki/Teknik Lise & 0,161 & 0,368 & 0,168 & 0,374 & 0,149 & 0,356 \\
\hline & Yüksekokul/Fakülte & 0,309 & 0,462 & 0,234 & 0,423 & 0,457 & 0,498 \\
\hline & Yüksek Lisans/Doktora & 0,018 & 0,134 & 0,014 & 0,117 & 0,027 & 0,163 \\
\hline & Eğitime Devam & 0,247 & 0,431 & 0,245 & 0,430 & 0,251 & 0,434 \\
\hline \multirow{19}{*}{$\begin{array}{c}\text { Ana Faaliyet Kolu } \\
\text { (Nace Rev 2) }\end{array}$} & Tarım, Ormancılık, Balıkçılık (Ref. Grup) & 0,032 & 0,176 & 0,031 & 0,172 & 0,035 & 0,183 \\
\hline & Madencilik, Taş Ocakçılığı & 0,004 & 0,061 & 0,005 & 0,071 & 0,001 & 0,030 \\
\hline & İmalat & 0,244 & 0,430 & 0,273 & 0,446 & 0,188 & 0,390 \\
\hline & Enerji & 0,005 & 0,069 & 0,006 & 0,079 & 0,002 & 0,045 \\
\hline & Su Temini, Kanalizasyon, Atık & 0,003 & 0,057 & 0,004 & 0,063 & 0,002 & 0,040 \\
\hline & İnşaat & 0,066 & 0,248 & 0,095 & 0,293 & 0,009 & 0,094 \\
\hline & Toptan \& Perakende Ticaret & 0,171 & 0,377 & 0,166 & 0,373 & 0,181 & 0,385 \\
\hline & Ulaştırma \& Depolama & 0,037 & 0,188 & 0,046 & 0,210 & 0,018 & 0,134 \\
\hline & Konaklama ve Yiyecek Hizmetleri & 0,091 & 0,288 & 0,107 & 0,309 & 0,061 & 0,239 \\
\hline & Bilgi ve İletişim & 0,013 & 0,114 & 0,015 & 0,120 & 0,010 & 0,099 \\
\hline & Finans ve Sigorta Faaliyetleri & 0,011 & 0,105 & 0,008 & 0,087 & 0,018 & 0,133 \\
\hline & Gayrimenkul Faaliyetleri & 0,005 & 0,068 & 0,005 & 0,070 & 0,004 & 0,064 \\
\hline & Mesleki, Bilimsel ve Teknik Faaliyetler & 0,040 & 0,196 & 0,029 & 0,168 & 0,061 & 0,240 \\
\hline & İdari ve Destek Hizmet Faaliyetleri & 0,039 & 0,193 & 0,037 & 0,190 & 0,041 & 0,199 \\
\hline & Kamu Yönetimi, Savunma & 0,064 & 0,245 & 0,074 & 0,262 & 0,044 & 0,205 \\
\hline & Eğitim & 0,069 & 0,253 & 0,029 & 0,169 & 0,147 & 0,354 \\
\hline & İnsan Sağlığı ve Sosyal Hizmetler & 0,064 & 0,245 & 0,028 & 0,166 & 0,134 & 0,341 \\
\hline & Kültür, Sanat, Eğlence, Dinlence Faaliyetleri & 0,009 & 0,092 & 0,008 & 0,089 & 0,010 & 0,098 \\
\hline & Diğer Hizmet Faaliyetleri & 0,031 & 0,174 & 0,032 & 0.177 & 0.029 & 0.167 \\
\hline \multirow{2}{*}{$\mathrm{Kamu} /$ Özel } & Özel Sektör (Ref. Grup) & 0,846 & 0,361 & 0,874 & 0,332 & 0,792 & 0,406 \\
\hline & Kamu Sektörü & 0,147 & 0,354 & 0,123 & 0,328 & 0,195 & 0,396 \\
\hline \multirow{9}{*}{$\begin{array}{l}\text { Meslek Grubu } \\
\quad \text { (Isco 08) }\end{array}$} & Yöneticiler & 0,014 & 0,116 & 0,014 & 0,116 & 0,014 & 0,117 \\
\hline & Profesyonel Meslek Grupları & 0,136 & 0,343 & 0,086 & 0,280 & 0,234 & 0,424 \\
\hline & Teknisyenler, Teknikerler ve Yrd. Meslek Grupları & 0,080 & 0,271 & 0,072 & 0,259 & 0,095 & 0,294 \\
\hline & Büro Hizmetinde Çalışanlar & 0,110 & 0,313 & 0,082 & 0,274 & 0,166 & 0,372 \\
\hline & Hizmet ve Satış Elemanları & 0,265 & 0,441 & 0,252 & 0,434 & 0,290 & 0,454 \\
\hline & Nitelikli Tarım Orman ve Su Ürünleri (Ref. Grup) & 0,008 & 0,089 & 0,010 & 0,098 & 0,005 & 0,068 \\
\hline & Sanatkârlar ve İlgili İşlerde Çalışanlar & 0,154 & 0,361 & 0,210 & 0,408 & 0,042 & 0,200 \\
\hline & Tesis ve Makine Operatörleri ve Montajcılar & 0,091 & 0,287 & 0,114 & 0,318 & 0,045 & 0,207 \\
\hline & Nitelik Gerektirmeyen İşlerde Çalışanlar & 0,143 & 0,350 & 0,160 & 0,367 & 0,109 & 0,312 \\
\hline
\end{tabular}




\begin{tabular}{|c|c|c|c|c|c|c|c|}
\hline \multirow{5}{*}{ Firma Ölçeği } & $<=10$ kiși & 0,376 & 0,484 & 0,403 & 0,491 & 0,322 & 0,467 \\
\hline & 11-19 kişi & 0,082 & 0,274 & 0,077 & 0,267 & 0,091 & 0,288 \\
\hline & 20-49 kiși & 0,198 & 0,399 & 0,191 & 0,393 & 0,213 & 0,410 \\
\hline & $>=50$ kişi & 0,342 & 0,474 & 0,327 & 0,469 & 0,371 & 0,483 \\
\hline & Bilmiyor, fakat $10^{\prime}$ dan fazla kişi & 0,002 & 0,046 & 0,002 & 0,044 & 0,002 & 0,049 \\
\hline Hanehalkındaki Kişi Sayısı & Hanehalkı Büyüklük & 4,430 & 2,288 & 4,543 & 2,344 & 4,208 & 2,156 \\
\hline Çalışma Deneyimi*** & Çalıșma Deneyim & 1,764 & 2,149 & 1,752 & 2,191 & 1,789 & 2,063 \\
\hline
\end{tabular}

Kaynak: 2019 HIAMVS.

* İyi işin özelliklerini hemen hemen aynı oranda en az gösteren bölgeler Batı Karadeniz ve Doğu Karadeniz Bölgeleri olduğu için her iki bölge de referans grup olarak alınmıştır.

** Mevcut işteki çalışmaya başlama yılı, başlangıç yılı olarak belirlenmiştir.

İstihdamdaki gençlerin \%74'ünün bekâr olmasından dolayı medeni durumda referans grubunu, daha az sayıdaki 'evli'ler oluşturmuştur. Kaliteli işin gerektirdiği en önemli niteliklerden biri olan eğitim düzeyi değişkeni; 'lise öncesi' (okur-yazar olmayan, okuryazar olup ilkokulu bitiremeyenler, ilkokul, ortaokul veya ilköğretim mezunu olanlar), 'lise ve sonrast' biçiminde gruplandırılmıştır. Lise düzeyinde eğitime sahip olanlar ' genel lise ve mesleki/teknik lise'; lise sonrası düzeyinde eğitime sahip olanlar ise 'yüksekokul, fakülte ve lisansüstü mezunu' olarak belirlenmiş ve referans grup olarak lise öncesi grup alınmıştır. Analizde kullanılan diğer değişkenler HİAMVS'nde gruplandırıldığı biçimiyle belirlenmiştir. Modelde kullanılan devamlı (kategorik olmayan) değişkenler, 'hanehalkı büyüklüğ̈̈' ve 'deneyim'dir. Tablo 3'te koyu olarak gösterilen gruplar ilgili kategorik değişkenler referans grubu olarak belirlenmiş ve model tahmini yapılmıştır. İyi işin tüm özelliklerini barındıran işlerde çalışan gençlerin oranı yaklaşık \%35'tir (Tablo 3).

\subsection{Model}

Çalışmanın kapsamını oluşturan 15-29 yaş grubundaki gençlerin çalıştıkları işlerin kalitesinin analizinde probit modeli kullanılmıştır. Probit modeli ikili ayrık seçim modeli olup, modelde bağımlı değişken 1 veya 0 değerini almaktadır. Modelin temeli en küçük kareler yönteminde kullanılan koşullu ortalamanın değil, koşullu olasılığın tahmin edilmesine dayanmaktadır. Dolayısıyla modeli doğrusal olasılık modeli kullanarak tahmin etmek sabit varyans, normal dağılım ve fonksiyonel form varsayımlarının bozulmasına neden olmaktadır. Ayrıca modelde katsayıların tahmininde mantıksız sonuçlar ortaya çıkmaktadır (Long, 2007). Bu sorunların giderilmesi için probit modeli hata terimlerinin normal dağıldığı varsayımı altında en çok olabilirlik yöntemi ile tahmin edilmektedir. İyi işte çalışma olasıllı̆̆ aşağıdaki gibi modellenmektedir:

$$
\operatorname{Pr}\left(y_{i}=1\right)=P_{i}=\Phi\left(Z_{i}\right)=\Phi\left(x_{i} \beta\right)
$$

İyi işte çalışma 1 , kötü işte çalışma ise 0 değerini almaktadır. $\Phi\left(Z_{i}\right)$ kümülatif yoğunluk fonksiyonudur. Hata terimlerinin ortalamasının $0,(E(\varepsilon \mid x)=0)$ ve varyansının 1 , $(\operatorname{var}(\varepsilon \mid x)=1)$ olduğu normal dağılım varsayımında elde edilen kümülatif yoğunluk fonksiyonu aşağıdaki gibidir:

$$
\Phi\left(Z_{i}\right)=\Phi\left(x_{i} \beta\right)=\int_{-\infty}^{\alpha+\beta x} \frac{1}{\sqrt{2 \pi \sigma^{2}}} \exp \left(-\frac{\left(y_{i}-x_{i} \beta\right.}{2 \sigma^{2}}\right) d x
$$

$x_{i}$ açıklayıcı değişkenleri, $\beta$ ise tahmini katsayıların vektörüdür. 
Probit modeli ise normal kümülatif yoğunluk fonksiyonunun tersi alınarak elde edilir:

$$
Z_{i}=F^{-1}\left(P_{i}\right)=x_{i} \beta
$$

Marjinal etki olasılık eğrisinin $x_{i}$ 'e göre türevi yani eğimidir. Sonuçların yorumlanmasında marjinal etki esas alınmış ve bir karakteristik özelliğin iyi işte çalışma olasılığının etkisine bakılırken, diğer değişkenler ortalamada tutulmuştur.

\subsection{Ekonometrik Model Sonuçları}

İkili ayrık seçim modellerinin en önemli avantajlarından birisi, 2019 HİAMVS çerçevesinde incelenen demografik ve sosyoekonomik unsurların iyi işte çalışma olasılığına etkisinin yüzdesel olarak yorumlanmasına olanak sağlamasıdır. Çalışmada istihdamın kalitesi, tabakalı işgücü piyasası kuramına göre ve cinsiyet farklılıkları dikkate alınarak modellenmiştir.

15-29 yaş grubundaki erkeklerin iyi işte çalışma olasılığı, kadınlara göre \%10 daha fazladır. İyi işte çalışma olasılığını etkileyen faktörler kadın ve erkeğe göre farklılık göstermektedir (Tablo 4). Yaş arttıkça ücret ve deneyime bağlı olarak, iyi işte çalışma olasılığı da artmaktadır. Modele göre, '25-29 yaş' grubundaki kadın ve erkekte iyi işte çalışma olasılığ1, '15-19 yaş' grubuna göre \%25 daha fazladır. 15-29 yaş grubunda 'bekar' olanların ' evli' olanlara göre iyi işte çalışma olasılığ̣, \%5,7 daha azdır. Bu oran kadınlar için yaklaşık \%4 iken, erkekler için yaklaşık \%7' dir. Erkek ve evli bireylerin iyi işlerde çalışma olasılığının yüksekliği toplumsal cinsiyetçi temelinde evi geçindirme yükümlülükleri ile açıklanabilir. Çalışmaya benzer biçimde, Dickens ve Lang (1992) ve Kumaş ve Çağlar'ın (2017), 15-64 yaş grubunda işin kalitesini inceledikleri çalışmalarında, evli olanların bekar olanlara göre iyi işte çalışma olasılığ 1 daha yüksek bulunmuştur.

Tablo: 4

Probit Model Sonuçları

\begin{tabular}{|c|c|c|c|c|c|c|}
\hline & \multicolumn{2}{|c|}{ Toplam } & \multicolumn{2}{|c|}{ Erkek } & \multicolumn{2}{|c|}{ Kadın } \\
\hline Değişkenler & Katsayı & Marjinal Etki & Katsayı & Marjinal Etki & Katsayı & Marjinal Etki \\
\hline \multicolumn{7}{|l|}{ Yaş Grubu (Ref. 15-19) } \\
\hline \multirow{2}{*}{$20-24$} & $0,665^{* * * *}$ & $0,142 * * *$ & $0,718^{* * * *}$ & $0,162 * * *$ & $0,585^{* * * *}$ & $0,138^{* * * *}$ \\
\hline & $(13,343)$ & $(14,873)$ & $(13,904)$ & $(15,608)$ & $(6,552)$ & $(7,325)$ \\
\hline \multirow{2}{*}{$25-29$} & $0,901^{* * * *}$ & $0,203 * * *$ & $1,054^{* * * *}$ & $0,254 * * *$ & $0,999 * * *$ & $0,254 * * * *$ \\
\hline & $(17,493)$ & $(19,506)$ & $(19,761)$ & $(22,556)$ & $(10,965)$ & $(12,646)$ \\
\hline \multirow{2}{*}{ Cinsiyet (Ref Erkek) } & $0,381 * * *$ & $0,089 * * *$ & & & & \\
\hline & $(14,528)$ & $(14,747)$ & & & & \\
\hline \multirow{2}{*}{ Medeni Durum (Ref. Evli) } & $-0,193 * * *$ & $-0,046 * * *$ & $-0,273^{* * * *}$ & $-0,0683^{* * * *}$ & $-0,164 * * *$ & $-0,0426 * * *$ \\
\hline & $(-7,268)$ & $(-7,147)$ & $(-9,120)$ & $(-8,950)$ & $(-3,778)$ & $(-3,727)$ \\
\hline \multicolumn{7}{|c|}{ Bölge (Ref. Batt ve Doğu Karadeniz) } \\
\hline \multirow{2}{*}{ İstanbul } & $0,676^{* * * *}$ & $0,157 * * *$ & $0,721 * * *$ & $0,164 * * *$ & $0,585^{* * * *}$ & $0,138^{* * * * *}$ \\
\hline & $(15,885)$ & $(15,949)$ & $(13,205)$ & $(13,299)$ & $(8,608)$ & $(8,591)$ \\
\hline \multirow{2}{*}{ Batı Marmara } & $0,317 * * *$ & $0,074 * * *$ & 0,366 **** & $0,083 * * *$ & $0,248 * * *$ & $0,059 * * *$ \\
\hline & $(5,780)$ & $(5,780)$ & $(5,153)$ & $(5,155)$ & $(2,868)$ & $(2,867)$ \\
\hline \multirow[b]{2}{*}{ Ege } & $0,384 * * *$ & 0,089 *** & $0,472 * * *$ & $0,108 * * * *$ & $0,218^{* * * *}$ & $0,051^{* * * * *}$ \\
\hline & $(8,533)$ & $(8,532)$ & $(8,201)$ & $(8,217)$ & $(3,012)$ & $(3,006)$ \\
\hline \multirow{2}{*}{ Doğu Marmara } & $0,438^{* * * * *}$ & $0,102 * * *$ & $0,545^{* * * *}$ & $0,124 * * *$ & $0,253 * * *$ & 0,059 *** \\
\hline & $(9,573)$ & $(9,598)$ & $(9,294)$ & $(9,350)$ & $(3,439)$ & $(3,435)$ \\
\hline \multirow{2}{*}{ Batı Anadolu } & $0,371^{*} * *$ & $0,086^{* * * *}$ & $0,448 * * *$ & $0,102 * * *$ & $0,211^{* * * *}$ & $0,049^{* * * *}$ \\
\hline & $(8,064)$ & $(8,070)$ & $(7,794)$ & $(7,813)$ & $(2,726)$ & $(2,722)$ \\
\hline
\end{tabular}


Erdem-Karahanoğlu, G. \& H. Kumaş (2022), “Türkiye'de İyi ve Kötü İşler:

Genç Çalışanlar Üzerinden Bir Analiz”, Sosyoekonomi, 30(51), 427-447.

\begin{tabular}{|c|c|c|c|c|c|c|}
\hline \multirow{2}{*}{ Akdeniz } & $-0,015$ & $-0,004$ & 0,055 & 0,012 & $-0,126^{*}$ & $-0,029 *$ \\
\hline & $(-0,324)$ & $(-0,324)$ & $(0,933)$ & $(0,932)$ & $(-1,682)$ & $(-1,684)$ \\
\hline \multirow{2}{*}{ Orta Anadolu } & $0,146^{* *}$ & $0,034^{* * *}$ & $0,210 * * *$ & $0,048 * * * *$ & $-0,007$ & $-0,002$ \\
\hline & $(2,554)$ & $(2,553)$ & $(2,935)$ & $(2,935)$ & $(-0,068)$ & $(-0,068)$ \\
\hline \multirow{2}{*}{ Kuzeydoğu Anadolu } & 0,052 & 0,012 & $-0,025$ & $-0,006$ & $0,204 * *$ & $0,048^{* * *}$ \\
\hline & $(0,877)$ & $(0,877)$ & $(-0,333)$ & $(-0,333)$ & $(2,063)$ & $(2,064)$ \\
\hline \multirow{2}{*}{ Orta Doğu Anadolu } & $-0,058$ & $-0,014$ & $-0,100$ & $-0,023$ & 0,041 & 0,010 \\
\hline & $(-1,052)$ & $(-1,052)$ & $(-1,367)$ & $(-1,367)$ & $(0,480)$ & $(0,480)$ \\
\hline \multirow{2}{*}{ Güney Doğu Anadolu } & $-0,113 * *$ & $-0,026^{* *}$ & $-0,204 * * *$ & $-0,047 * * *$ & 0,094 & 0,022 \\
\hline & $(-2,234)$ & $(-2,235)$ & $(-3,117)$ & $(-3,123)$ & $(1,153)$ & $(1,153)$ \\
\hline \multicolumn{7}{|l|}{ Eğitim (Ref. Lise Öncesi) } \\
\hline \multirow{2}{*}{ Genel Lise } & $0,111 * * *$ & $0,026^{* * * *}$ & $0,082 *$ & $0,019^{*}$ & $0,241 * * *$ & $0,054 * * *$ \\
\hline & $(2,805)$ & $(2,775)$ & $(1,761)$ & $(1,744)$ & $(2,910)$ & $(2,893)$ \\
\hline \multirow{2}{*}{ Mesleki/Teknik Lise } & 0,387 **** & $0,094 * * *$ & $0,345^{* * * *}$ & 0,083 **** & $0,522 * * *$ & 0,124 **** \\
\hline & $(11,641)$ & $(11,401)$ & $(9,139)$ & $(8,905)$ & $(6,956)$ & $(7,049)$ \\
\hline \multirow{2}{*}{ Yüksekokul/Fakülte } & $0,573 * * *$ & $0,143^{* * *} *$ & $0,544 * * *$ & $0,134 * * *$ & $0,710 * * *$ & 0,174 *** \\
\hline & $(16,603)$ & $(15,872)$ & $(13,248)$ & $(12,480)$ & $(9,711)$ & $(9,883)$ \\
\hline \multirow{2}{*}{ Yüksek Lisans/Doktora } & $0,959^{* * *}$ & 0,248 *** & $0,854 * * * *$ & $0,216^{* * * * *}$ & $1,162 * * *$ & $0,302 * * *$ \\
\hline & $(9,978)$ & $(9,365)$ & $(6,510)$ & $(6,159)$ & $(7,751)$ & $(7,164)$ \\
\hline \multirow{2}{*}{ Eğitime Devam } & $-0,118 * * *$ & $-0,027 * * *$ & $-0,124 * * *$ & $-0,028 * * *$ & $-0,115^{* * *}$ & $-0,027 * *$ \\
\hline & $(-4,199)$ & $(-4,200)$ & $(-3,534)$ & $(-3,535)$ & $(-2,406)$ & $(-2,404)$ \\
\hline Sektör (Ref. Tarım, Ormancılık, Balıkçılık) & & & & & & \\
\hline & $1,270^{* * * *}$ & $0,296 * * *$ & $1,284 * * *$ & $0,293 * * *$ & 0,426 & 0,101 \\
\hline Madencilik, Taş Ocakçılığı & $(6,423)$ & $(6,426)$ & $(5,626)$ & $(5,631)$ & $(0,874)$ & $(0,874)$ \\
\hline & $0,748^{* * * *}$ & $0,174 * * *$ & $0,694 * * *$ & $0,158 * * *$ & $0,932 * * *$ & 0,220 *** \\
\hline Imalat & $(4,812)$ & $(4,810)$ & $(3,668)$ & $(3,667)$ & $(3,065)$ & $(3,064)$ \\
\hline & $1,035 * * *$ & $0,241 * * *$ & $1,027 * * * *$ & $0,234 * * * *$ & $0,978 * *$ & 0,231 ** \\
\hline Enerji & $(5,403)$ & $(5,401)$ & $(4,569)$ & $(4,569)$ & $(2,339)$ & $(2,338)$ \\
\hline & $0,767 * * *$ & $0,179 * * *$ & $0,632 * *$ & $0,144 * * *$ & $0,990 * *$ & $0,234^{* *}$ \\
\hline Su teminı, Kanalızasyon, Atık & $(3,636)$ & $(3,636)$ & $(2,506)$ & $(2,51)$ & $(2,216)$ & $(2,216)$ \\
\hline & $0,640 * * *$ & $0,149 * * *$ & $0,554 * * *$ & $0,126^{* * * *}$ & $1,110 * * *$ & 0,262 *** \\
\hline Inşaat & $(3,980)$ & $(3,980)$ & $(2,861)$ & $(2,860)$ & $(3,209)$ & $(3,210)$ \\
\hline & $0,777 * * *$ & $0,181^{*} * *$ & $0,671 * * *$ & $0,153 * * *$ & $1,103^{* * *}$ & $0,260 * * *$ \\
\hline Toptan \& Perakende Ticaret & $(5,024)$ & $(5,024)$ & $(3,558)$ & $(3,559)$ & $(3,670)$ & $(3,669)$ \\
\hline & $0,806^{* * * *}$ & $0,188^{* * * *}$ & $0,646^{* * * *}$ & 0,147 **** & $1,453 * * *$ & 0,343 *** \\
\hline Ulaştırma \& Depolama & $(4,934)$ & $(4,932)$ & $(3,273)$ & $(3,271)$ & $(4,489)$ & $(4,495)$ \\
\hline & $0,748^{*} * *$ & 0,174 **** & $0,715^{* * * *}$ & $0,163 * * *$ & $0,892 * * *$ & 0,211 *** \\
\hline Konaklama ve Yıyecek Hizmetlerı & $(4,755)$ & $(4,753)$ & $(3,741)$ & $(3,740)$ & $(2,885)$ & $(2,886)$ \\
\hline & $0,778^{* * *} *$ & $0,181^{* * *} *$ & $0,676^{* * *}$ & $0,154 * * *$ & $1,227 * * *$ & $0,290 * * *$ \\
\hline Bilgi ve lletişim & $(4,344)$ & $(4,346)$ & $(3,111)$ & $(3,111)$ & $(3,573)$ & $(3,576)$ \\
\hline & $1,095 * * *$ & $0,255 * * *$ & 1,030 **** & 0,235 **** & $1,317 * * *$ & 0,311 *** \\
\hline Finans ve Sigorta Faaliyetlerı & $(6,019)$ & $(6,028)$ & $(4,534)$ & $(4,536)$ & $(3,984)$ & $(3,994)$ \\
\hline & $0,826^{* * * *}$ & $0,192 * * *$ & $0,761 * * *$ & $0,173 * * *$ & $1,033 * * *$ & $0,244 * * *$ \\
\hline Gayrımenkul Faalıyetlerı & $(4,035)$ & $(4,035)$ & $(3,041)$ & $(3,040)$ & $(2,704)$ & $(2,704)$ \\
\hline & 0,760 **** & 0,177 **** & $0,724 * * *$ & $0,165 * * *$ & $0,942 * * *$ & $0,223 * * *$ \\
\hline Meslek1, Bılımsel ve Teknık Faalıyetler & $(4,664)$ & $(4,666)$ & $(3,561)$ & $(3,562)$ & $(3,055)$ & $(3,057)$ \\
\hline & $0,906^{* * * *}$ & 0,211 **** & $0,882^{*} * * *$ & $0,201 * * *$ & $1,074 * * *$ & $0,254 * * *$ \\
\hline Idarı ve Destek Hizmet Faalıyetlerı & $(5,657)$ & $(5,657)$ & $(4,522)$ & $(4,523)$ & $(3,445)$ & $(3,444)$ \\
\hline Кати Yönetimi Sayunma & $0,997 * * *$ & $0,232 * * *$ & 0,633 *** & $0,144 * * *$ & $1,379 * * *$ & $0,326 * * *$ \\
\hline Kamu Yonetımı, Savunma & $(6,030)$ & $(6,029)$ & $(3,034)$ & $(3,033)$ & $(4,412)$ & $(4,412)$ \\
\hline & 0,069 & 0,016 & $-0,147$ & $-0,033$ & 0,397 & 0,094 \\
\hline Eğitım & $(0,424)$ & $(0,424)$ & $(-0,692)$ & $(-0,693)$ & $(1,297)$ & $(1,297)$ \\
\hline & $0,512 * * *$ & $0,119^{* * *}$ & 0,306 & 0,069 & $0,793 * * *$ & 0,187 **** \\
\hline Insan Sağlığı ve Sosyal Hizmetler & $(3,191)$ & $(3,190)$ & $(1,471)$ & $(1,470)$ & $(2,608)$ & $(2,606)$ \\
\hline & $0,342^{*}$ & $0,079 *$ & 0,172 & 0,039 & $0,690 *$ & $0,163^{*}$ \\
\hline Kültür, Sanat, Eğlence, Dinlence Faaliyetleri & $(1,736)$ & $(1,735)$ & $(0,704)$ & $(0,703)$ & $(1,895)$ & $(1,893)$ \\
\hline & $0,462 * * *$ & $0,108^{*} * * *$ & $0,469 * *$ & $0,107 * *$ & 0,432 & 0,102 \\
\hline Diğer Hizmet Faaliyetleri & $(2,700)$ & $(2,699)$ & $(2,275)$ & $(2,275)$ & $(1,230)$ & $(1,229)$ \\
\hline & $0,774 * * *$ & $0,180^{* * * *}$ & $1,120 * * *$ & $0,255 * * *$ & $0,516^{* * * *}$ & $0,122 * * *$ \\
\hline Kamu-Ozel (Ref. Ozel) & $(16,050)$ & $(16,231)$ & $(13,924)$ & $(14,135)$ & $(8,346)$ & $(8,379)$ \\
\hline Meslek Grubu (Ref. Tesis ve makine operatörleri & ntajcular) & & & & & \\
\hline Yöneticiler & $1,178^{* * * *}$ & $0,285^{* * *}$ & $1,127 * * *$ & $0,267 * * *$ & $1,085 * * *$ & $0,268 * * *$ \\
\hline Yoneticiler & $(10,378)$ & $(10,487)$ & $(7,536)$ & $(7,614)$ & $(5,744)$ & $(5,792)$ \\
\hline & $0,661^{* * * *}$ & $0,160^{* * * *}$ & $0,623 * * * *$ & $0,147 * * *$ & $0,532 * * *$ & 0,132 *** \\
\hline Profesyonel Meslek Grupları & $(11,450)$ & $(11,602)$ & $(8,583)$ & $(8,689)$ & $(4,140)$ & $(4,172)$ \\
\hline & $0,399 * * *$ & $0,097 * * *$ & $0,401 * * * *$ & $0,095 * * *$ & $0,269 * *$ & 0,067 ** \\
\hline Teknisyenler, Teknikerler ve Yrd. Meslek Grupları & $(7,356)$ & $(7,404)$ & $(6,309)$ & $(6,350)$ & $(2,093)$ & $(2,100)$ \\
\hline Büro Hizmetinde Calıanlar & 0,035 & 0,008 & 0,045 & 0,011 & $-0,108$ & $-0,027$ \\
\hline Buro Hizmetinde Çalişanlar & $(0,679)$ & $(0,679)$ & $(0,735)$ & $(0,735)$ & $(-0,865)$ & $(-0,864)$ \\
\hline
\end{tabular}




\begin{tabular}{|c|c|c|c|c|c|c|}
\hline \multirow{2}{*}{ Hizmet ve Satış Elemanları } & $0,091^{*}$ & $0,022^{*}$ & $0,138^{* *}$ & $0,033^{*}$ & $-0,145$ & $-0,036$ \\
\hline & $(1,896)$ & $(1,898)$ & $(2,569)$ & $(2,572)$ & $(-1,150)$ & $(-1,149)$ \\
\hline \multirow{2}{*}{ Sanatkârlar ve İlgili İşlerde Çalışanlar } & 0,013 & 0,003 & 0,044 & 0,011 & $-0,317 * *$ & $-0,078 * *$ \\
\hline & $(0,282)$ & $(0,282)$ & $(0,894)$ & $(0,895)$ & $(-2,248)$ & $(-2,244)$ \\
\hline \multirow{2}{*}{ Nitelik Gerektirmeyen İşlerde Çalışanlar } & $-0,363^{* * *}$ & $-0,088^{* * * *}$ & $-0,358^{* * * *}$ & $-0,085^{* * * *}$ & $-0,457 * * *$ & $-0,113 * * *$ \\
\hline & $(-7,234)$ & $(-7,232)$ & $(-6,470)$ & $(-6,466)$ & $(-3,458)$ & $(-3,454)$ \\
\hline \multicolumn{7}{|l|}{ İşletme Büyüklüğü (Ref. 11-19 kişi) } \\
\hline \multirow{2}{*}{$<=10$ kişi } & $-0,259 * * *$ & $-0,060^{* * * *}$ & $-0,294^{* * * *}$ & $-0,067 * * * *$ & $-0,164 * *$ & $-0,039 * *$ \\
\hline & $(-5,973)$ & $(-5,986)$ & $(-5,357)$ & $(-5,376)$ & $(-2,294)$ & $(-2,295)$ \\
\hline \multirow{2}{*}{ 20-49 kişi } & $0,170 * * *$ & 0,039 **** & $0,182 * * *$ & $0,042 * * *$ & $0,135^{*}$ & $0,032 *$ \\
\hline & $(3,775)$ & $(3,778)$ & $(3,159)$ & $(3,163)$ & $(1,833)$ & $(1,834)$ \\
\hline \multirow{2}{*}{$>=50$ kişi } & $0,416^{* * * *}$ & $0,097 * * * *$ & $0,430 * * *$ & $0,098 * * *$ & $0,386^{* * * *}$ & $0,091^{* * * *}$ \\
\hline & $(9,664)$ & $(9,746)$ & $(7,842)$ & $(7,898)$ & $(5,470)$ & $(5,520)$ \\
\hline \multirow{2}{*}{ Hanehalkı Büyüklüğü } & $-0,083 * * *$ & $-0,019 * * *$ & $-0,074 * * *$ & $-0,017 * * *$ & $-0,110 * * *$ & $-0,026 * * *$ \\
\hline & $(-11,519)$ & $(-11,824)$ & $(-8,603)$ & $(-8,822)$ & $(-8,039)$ & $(-8,256)$ \\
\hline \multirow{2}{*}{ Çalışma Deneyim } & $0,118^{* * * *}$ & $0,028 * * * *$ & $0,110 * * *$ & $0,025 * * *$ & $0,142 * * *$ & $0,033^{* * * *}$ \\
\hline & $(21,012)$ & $(21,722)$ & $(16,038)$ & $(16,525)$ & $(13,895)$ & $(14,557)$ \\
\hline \multirow{2}{*}{ Sabit } & $-2,959 * * *$ & & $-2,747^{* * * *}$ & & $-2,422^{* * * *}$ & \\
\hline & $(-15,776)$ & & $(-11,890)$ & & $(-8,143)$ & \\
\hline $\mathrm{N}$ & 28.542 & & 19.085 & & 9.457 & \\
\hline Pseudo $\mathrm{R}^{2}$ & 0,358 & & 0,372 & & 0,348 & \\
\hline
\end{tabular}

Not: Parantez içindekiler t istatistikleri olup hem katsayı hem de marjinal etkinin yanında yer alan

*\%10 seviyesinde anlamll;

**\%5 seviyesinde anlamll;

***\%1 seviyesinde anlamlı olduğunu göstermektedir.

İşin kalitesi, bölgesel özelliklere veya farklılıklara göre değişebilmektedir (Tablo 4). Küresel boyutta gelişmiş bölgelerde işgücü piyasası temel göstergelerine göre gençlerin iyi iş bulma olasılığ daha yüksektir. Ancak her gelişmiş bölge genç kadın ve erkek için aynı oranda iyi işte çalışma olasılığı sunmamaktadır (ILO, 2016: 73-143). Tarımda çalışmanın yaygın ancak sanayileşmenin daha az olduğu 'Batı ve Doğu Karadeniz Bölgelerine' göre, erkekler için iyi işte çalışma olasıllğının en yüksek olduğu bölgeler sırasıyla, 'İstanbul, Doğu Marmara, Ege, Batı Anadolu ve Batı Marmara'dır. Istanbul Bölgesi, erkeklere benzer biçimde kadınlar için de iyi işte çalışma olasılığının en yükssek olduğu işgücü piyasasıdır. Ancak İstanbul gibi sanayileşmiş bölgeler olan 'Doğu Marmara, Batı Anadolu, Ege ve Batı Marmara Bölgeleri'nde iyi işte çalışma olasılığı kadınlarda erkeklere göre çok daha düşüktür. Batı ve Doğu Karadeniz Bölgeleri ile karşılaştırıldığında gelişmişlik düzeyi daha yüksek bir bölge olan 'Akdeniz Bölgesi'nde kadınların iyi işte çalışma olasıllığ1 \%3 azalmıştır. Bu durum 'Akdeniz Bölgesi'nde genç kadınların ortalama ücretlerinin referans gruba göre daha düşük olması ile açıklanabilir (Akdeniz Bölgesi’nde geçen ay elde edilen net ortalama gelir ÜMY kadın için 1.832 TL iken, referans gruptaki kadınlar için 2.071 TL'dir).

Tabakalı işgücü piyasası kuramına göre, eğitim düzeyi ile birincil piyasada çalışma olasılığı arasında anlamlı bir ilişsi vardır (Doeringer \& Piore, 1970). İnan ve Aşık (2015), Türkiye'de lise ve üzeri eğitim düzeylerinin özellikle kadınlarda işgücüne katılımı artırmada belirgin kazanımlar yarattığını vurgulamıştır. Modele göre de her iki cinsiyet için de eğitim düzeyinin artması iyi işte çalışma olasılı̆̆ını artırmaktadır. Bu olasılık, genç erkeklere göre genç kadınlarda çok daha fazladır ve eğitim düzeyi arttıkça fark da artmaktadır. Örneğin; 'lisansüstü' eğitime sahip erkeklerin, 'lise öncesi' eğitime sahip erkeklere göre iyi işte çalışma olasılıkları \%21,6 daha fazla iken, kadınlar için bu olasılık \%30 daha fazladır. 
İşin kalitesi sektör ve meslekler açısından farklılıklar göstermektedir. Analiz sonuçlarına göre iyi işte çalışma olasılığının en yüksek olduğu sektörler sırasıyla; 'Maden ve Taş Ocakçılı̆̆l, Finans ve Sigorta Hizmetleri, Enerji ve Kamu Yönetimi ile Savunma'dır. 'Tarım, Ormancılık ve Balıkçılık Sektörü’ ile karşılaştırıldığında, kadınların iyi işte çalışma olasılığının en yüksek olduğu sektör, \%34 ile "Ulaştırma ve Depolama 'dır: 'Ulaştırma ve Depolama Sektörü'ndeki kadınlar için net ücret, 2.331 TL iken, referans grup için çalışan yoksul olduklarını gösterir biçimde, 679 TL'dir. 'Ulaştırma ve Depolama' sektöründeki kadınların \%59'unun eğitim düzeyi en az ön lisans iken, referans grupta bu oran \%7'dir. 1529 yaş grubu erkek çalışanların iyi işte çalışma olasılığının en yüksek olduğu sektör \%29 ile 'Maden ve Taş Ocakçılığı' sektörüdür. Bu sektörde çalışanların büyük çoğunluğu erkektir. Çünkü sektördeki işlerin ağır ve tehlikeli olması, iş yasaları gereği erkeğin çalışmasına olanak vermektedir. Yine iş yasalarına göre sektörde haftalık çalışma süresinin daha kısa olması (37,5 saat), sektörde çalışanların daha fazla ortalama ücret (2.543 TL) almalarına neden olmaktadır (15-29 yaş grubundaki ÜMY'ler için geçen ay elde edilen net ortalama gelir 2.131 TL'dir). Sektör açısından kadın ve erkek arasında iyi işte çalışma olasılığının, kadının lehine en yüksek oranda farklılık gösterdiği sektörler, 'Ulaştırma ve Depolama' (fark, \%19,6) ile 'Кати ve Savunma' (fark \%18,2)'dır.

Modelin göre, özel sektöre göre kamu sektöründe çalışmak, iyi işte çalışma olasılığını her iki cinsiyet için de anlamlı düzeyde artırmaktadır. Kamu sektöründe iyi işte çalışma olasılığı, erkeklerde (\%26), kadınlara göre (\%12) iki kat daha fazladır. Bu durum, özel sektöre göre kamu sektörünün, kuramın belirttiği gibi iyi iş göstergelerini ve özellikle uzun süreli ve güvenceli işleri daha fazla sağlamasından kaynaklanmaktadır. Verilere göre, kamu sektöründe çalışanların ortalama ücretleri 3.553 TL iken, özel sektörde çalışanların ise 1.834 TL'dir. Kamu sektöründe çalışanların \%67'sinin en az ön lisans düzeyinde eğitime sahip olması (özel sektörde \%24), kamu sektöründeki işlerin niteliğinin yüksek beceri getirmesi ile açıklanabilir. Nitekim kamu sektöründe çalışanların \%45'i 'Profesyonel Meslek', \%21'i 'Hizmet ve Satış Elemanları' ve \%13'ü 'Teknisyenler, Teknikler ve Yardımc Meslek' gruplarında yer almaktadır.

Modelin bir diğer bulgusu, meslek grupları ile iyi işte çalışma olasılığı arasında anlamlı bir ilişki olduğudur: Kadın ve erkek için iyi işte çalışma olasılığını en yüksek oranda artıran meslekler 'Tesis, Makine Operatörleri ve Montajcılar Meslek Grubu'na göre, 'Yönetici' ve 'Profesyonel Meslek Grubu' ve 'Teknisyenler, Teknikerler ve Yardımcı Meslekler'dir. Geçen ay esas işten elde edilen ortalama net gelir 'Yönetici' için 3.674 TL, 'Profesyonel Meslek Grubu' için 3.615 TL ve 'Teknisyenler, Teknikerler ve Yardımcı Meslekler' için 2.497. Söz konusu meslekler, yüksek eğitim, beceri ve nitelik gerektirdiği için ücretler de ortalamanın üzerindedir. Dolayısıyla bulgular, iyi işin yüksek nitelik gerektiren işler olduğu iddiasını desteklemektedir.

Bu çalışmada yazınla örtüşür biçimde, işletme ölçeği ile işin kalitesi arasında anlamlı bir ilişki gözlenmiştir: '11-19 Çalışanın Olduğu Küçük Ölçekli İşletme Ölçeği'ne göre '10’dan Az Çalışanın Olduğu Mikro İşletmeler'de çalışmak iyi işte çalışma olasılığını kadın ve erkekte yaklaşık \%6 oranında azaltmaktadır. Referans gruba göre her iki cinsiyet içinde 
iyi işte çalışma olasılığının en fazla gözlendiği işletme büyüklüğü, '50 ve daha fazla çalışanın olduğu' işletmelerdir. İşletme ölçeğinin büyümesinin iyi işte çalışma olasılığını artırmasında en belirgin unsur, çalışma saatleri ve ücret arasındaki ilişki olarak tespit edilmiştir. Haftalık çalışma süreleri, işletme ölçeklerine göre yaklaşık değerlerde olmasına rağmen, ortalama ücretlerde ciddi bir fark bulunmaktadır. Çalışan sayısı 10'dan az olan işletmelerde haftalık çalışma süresi 43 saat, ortalama ücret 1.579 TL iken, 50'den fazla çalışanın olduğu işletmelerde haftalık çalışma süresi 45 saat, ortalama ücret ise 2.697 TL'dir.

Modele göre hanehalkı büyüklüğü 'bir' kişi arttıkça, iyi işte çalışma olasılı̆̆g, yaklaşık \%2 oranında azalmaktadır: Dört kişiden daha fazla kişinin olduğu hanelerde yaşayan ve ÜMY olarak çalışan 15-29 yaş arası gençlerin, 'geçen ayki esas işlerinden elde ettikleri ortalama net gelirleri', 1.624 TL'dir. Söz konusu gençlerin ortalama ücretleri, 2019 y1lı için 'eşi çalışmayan ve eşi çalışan ve en az iki çocuklu bir kişinin' net asgari ücretinin ortalaması olan 2.133 TL'nin altındadır. Bu noktada, kuramın gelir dağılımının alt gruplarında yaşayan bireylerin dışsal piyasada çalıştıkları iddiası desteklenmektedir.

Çalışma kapsamındaki gençlerin ortalama ‘deneyim' süreleri, bir yıl yedi ay’dır: ‘İyi iş’te çalışanların deneyim süresi ortalama yaklaşık üç y1l, 'kötü iş’te çalışanların ise ortalama yaklaşık bir yıldır. Çalışma deneyiminin bir yıl artması, iyi işte çalışma olasılığını \%3 artırmaktadir.

\section{Sonuç ve Değerlendirme}

Tabakalı işgücü piyasaları genellikle gelişmekte olan ülkelerin temel özelliklerinden biri olarak kabul edilmektedir (Pages \& Stampini, 2009: 387). Bu çalışmada 'Tabakalı İşü̈cü Piyasası Kuramı'nın işlerin özelliğine bağlı olarak ayırdığı ikili işgücü piyasası yapısı genç çalışanlar üzerinden test edilmiş ve kuramın iddiasını geçerli kılacak biçimde, Türkiye işgücü piyasasının 15-29 çalışan yaş grubu açısından tabakalaştığı tespit edilmiştir. 2019 HİAMVS'nden elde edilen probit modeli sonuçlarına göre referans gruplarla karşılaştırıldığında; 25-29 yaş grubunda olmak, evli olmak, lisansüstü eğitim düzeyine sahip olmak, Maden ve Taş Ocakçıllğ̆l, Finans ve Sigorta Faaliyetleri ve Enerji sektörlerinde çalışmak, İstanbul'da yaşamak, yöneticilik meslek grubunda, en az 50 çalışanın olduğu işletmelerde ve kamu sektöründe çalışmak, iyi işte çalışma olasılığını en fazla artıran faktörlerdir. ' $\dot{I}_{\text {Ş}}$ 'te deneyim artıkça, iyi işte çalışma olasılığı artmaktadır. Diğer yandan, hanehalkı büyüklüğünün artması, iyi işte çalışma olasılığını azaltmaktadır. Hanehalk1 büyüklüğünün geleneksel bakış açısı ile erken yaşta eve katkı veya evi geçindirme sorumluluklarını artırması, gençlerin kötü işleri kabul etmelerine neden olabilir. Bu durum ayrıca, Türkiye işgücü piyasasının yeterince kurumsallaşmamış ve gelişmemiş yapısı ile de açıklanabilir. Model sonuçlarına göre gençlerin sosyo-demografik özelliklerinin, iyi ve kötü işte çalışmalarını belirlediği gözlenmiştir.

Elde edilen bulgular çalışmanın temel eseri olan Doeringer ve Piore (1970) ve Ashton et al. (2009), López-Roldán ve Fachelli (2020) ve López-Roldán et al. (2021), Stavik ve 
Hammer (2000), Lukac et al. (2019), Aydın (2009), Kumaş vd. (2014) ve Kumaş ve Çağlar'ın (2017) bulguları ile örtüşmektedir.

İşüüü piyasasındaki tabakalaşmayı uygulamalar ile belirlemek araştırmacılar için bazı zorluklara neden olmaktadır (Hodson \& Kaufman, 1982: 732-735; Hudson, 2007: 291): Birincisi, bu çalışmanın da temel kısıtlarından birisi olan işin kalitesini ölçen tüm değişkenlerin veri tabanlarında yer almamasıdır. Dolayısıyla bu durum, analizlerin sektör veya meslek eşdeğerliliklerine göre yapılmasına, neden ve sonuçların karışıklığına yol açmaktadır. Ancak tüm sınırlıklara rağmen kuram işgücünün doğası ve işleyişi hakkında bilgi verebilmekte ve araştırmalarda kuramın sunmuş olduğu ikili yapı gözlenebilmektedir (Hudson, 2007: 291). Tabakalı İşü̈cü Piyasası Kuramı (Doeringer \& Piore, 1970: 271), birincil/içsel piyasadaki işleri, iyi işlerin belirtilen tüm özellikleri içerisinden birkaç özelliği bir arada barındıran işler olarak tanımlamıştır. Mikro Veri Setine göre Türkiye'de 15-29 yaş grubundaki gençlerin yaklaşık \%65'i, iyi işin özelliklerinden birini barındırmamayı ifade eden 'kötü iş' lerde çalışmaktadır.

İlgili yazındaki araştırmaların çoğu, Tabakalı Işsǚcü Piyasası Kuramı'nı arz yönüyle test etmektedir. Gelecekteki çalışmalarda işin kalitesinin gruplandırılması arz yönlü, zaman ve piyasaya göre değişebilen unsurlara bağlı olarak incelenebileceği gibi (Daw \& Hardie, 2012: 1182; Kumaş \& Çağlar, 2017: 59), talep yönlü biçimde firma düzeyinde mikro veri setleri aracılığı ile incelenebilir. Kuramın geçerliliğini talep yönüyle analiz eden çalışmaların artması, ilgili yazına katkı sağlayabilecek ve işgücü piyasasına yönelik politikaların da başarısını artırabilecektir. Ayrıca, iyi işin özelliklerinin hepsinin aynı anda aranmadığı ve kötü iş ve iyi işin özelliklerini aynı anda barındıran ' gri alan' üzerinden analizlerin yapılması kuramın Türkiye işgücü piyasası açısından farklı boyutları ile test edilmesini sağlayabilecektir.

\section{Kaynaklar}

Anderson, K. et al. (1987), "Labour Market Segmentation: A Cluster Analysis of Job Groupings and Barriers to Entry", Southern Economic Journal, 53(3), 571- 590.

Anselme, M. \& R. Weisz (1985), "Good jobs and Bad: A Differentiated Structuring of the Labour Market”, Acta Sociologica, 28(1), 35-53.

Ashton, D. et al. (1990), The Segmentation of the Youth Labour Market, Cambridge: Cambridge Studies in Sociology.

Averitt, R.T. (1968), The Dual Economy: The Dynamics of American Industry Structure, New York: Norton.

Aydın, E. (2009), "Formel ve Enformel Sektör Ücret Farklılıkları: Katmanlı İşücü Piyasası Kuramının Türkiye Emek Piyasasına Uygulanması”, İstanbul Teknik Üniversitesi, Sosyal Bilimler Enstitüsü, Yüksek Lisans Tezi.

Bauder, H. (2001), "Culture in The Labour Market: Segmentation Theory and Perspectives of Place", Progress in Human Geography, 25(1), 37-52. 
Berndt, C. (2014), “Labour Market Segmentation”, in: The Wiley-AAG International Encyclopaedia of Geography,

<https://www.researchgate.net/publication/263444678_Berndt_C_2014_Labor_Market_ Segmentation_Submitted_for_publication_in_The_Wiley-

AAG_International_Encyclopedia_of_Geography>, 15.04.2021.

Bosanquet, N. (1987), "Internal Labour Markets and Education”, in: G. Psacharopoulos (ed.), Economics of Education Research and Studies (164-166), Oxford, New York: Pergamon.

Cain, G.G. (1976), "The Challenge of Segmented Labour Market Theories to Orthodox Theory: A Survey", Journal of Economic Literature, 14, 1215-1257.

Daw, J. \& J.H. Hardie (2012), "Compensating Differentials, Labour Market Segmentation, and Wage Inequality”, Social Science Research, 41(5), 1179-1197.

Dickens, W.T. \& K. Lang (1988), "The Reemergence of Segmented Labour Market Theory”, American Economic Review, 78(2), 129-134.

Dickens, W.T. \& K. Lang, (1992), "Labour Market Segmentation Theory: Reconsidering the Evidence", NBER Working Paper No. 4087, Cambridge.

Doeringer, P.B. \& M.J. Piore (1970), Internal Labour Markets and Manpower Analysis, USA Department of Labour: Eric.

Eriksson, T. \& A. Werwatz, (2005), The Prevalence of Internal Labour Markets- New Evidence from Panel Data, <https://core.ac.uk/download/pdf/7107253.pdf〉, 10.04.2021.

Fishman, E. \& A. Kimhi (2013), “Is the Israeli Labour Market Segmented?”, Taub Centre for Social Policy Studies in Israel Research Paper Series, No:13.01.

Hodson, R. \& R.L. Kaufman (1982), “Economic Dualism: A Critical Review”, American Sociological Review, (47), 727-739.

Horn, R.N. (1980), “A Case Study of the Dual Labour Market Hypothesis”, Journal of Economic Issues, 14(3), 615-630.

Hudson, K. (2007), “The New Labour Market Segmentation: Labour Market Dualism in the New Economy", Social Science Research, 36, 286-312.

ILO (2016) Non-Standard Employment Around the World: Understanding Challenges, Shaping Prospects, <https://www.ilo.org/wcmsp5/groups/public/---dgreports/---dcomm/--publ/documents/publication/wcms_534326.pdf>, 03.12.2021.

ILO (2017) Global Employment Trends for Youth 2017- Paths to a Better Working Future, <https://www.ilo.org/wcmsp5/groups/public/---dgreports/---dcomm/--publ/documents/publication/wcms_598669.pdf>, 15.03.2021.

ILO (2020), Global Employment Trends for Youth 2020 Technology and the Future of Jobs, <https://www.ilo.org/global/publications/books/WCMS_737648/lang--en/index.htm>, 18.03.2021.

ILO (2021a), Employment Security, Labour Market Segmentation, <http://www.ilo.org/global/topics/employment-security/labour-marketsegmentation/lang--en/index.htm>, 16.03.2021.

ILO (2021b), Youth and COVID-19: Access to Decent Jobs amid the Pandemic, <https://www.ilo.org/wcmsp5/groups/public/---europe/---ro-geneva/---iloankara/documents/publication/wcms_771428.pdf>, 04.04.2021. 
ILO (N/A), ILO Glossary of Statistical Terms, <https://www.ilo.org/ilostatfiles/Documents/Statistical\%20Glossary.pdf>, 03.12.2021.

İnan, F. \& G. Aşık (2015) Making Economies Work for Women: Female Labour Force Participation in Turkey, Ankara: TEPAV.

Jakštienė S. (2010), "Labour Market Segmentation: Theoretical Aspect", Ekonomika ir Vadyba: Aktualijos ir Perspektyvos, 4(20), 53-63.

Kalleberg, A.L. \& S. Vaisey (2005), "Pathways to a Good Job: Perceived Work Quality among the Machinists in North America", British Journal of Industrial Relations, 43(3), 431-454.

Kalleberg, A.L. (2003), "Flexible Firms and Labour Market Segmentation”, Work and Occupations, 30(2), 154-175.

Kalleberg, A.L. (2012), “Job Quality and Precarious Work: Clarifications, Controversies, and Challenges", Work and Occupations, 39(4), 427-448.

Kalleberg, A.L. et al. (1981), "Economic Segmentation, Worker Power, and Income Inequality", American Journal of Sociology, 87(3), 651-683.

Kalleberg, A.L. et al. (2000), "Bad Jobs in America: Standard and Nonstandard Employment Relations and Job Quality in the United States", American Sociological Review, 65(2), 256-278.

Kalleberg, A.L. et al. (2009), "Is Participation Good or Bad for Workers? Effects of Autonomy, Consultation and Teamwork on Stress Among Workers in Norway", Acta Sociologica, 52(2), 99-116.

Karaalp-Orhan, H.S. \& D. Aksoylu (2018), "Ücret Farklılıklarına Neden Olan Faktörler ve İşgücü Piyasasında Tabakalaşma: Ankara İli İnşaat Sektörü Üzerine Bir Alan Araştırması”, Yönetim ve Ekonomi Araştırmalar Dergisi, 16(2), 1-20.

Kumaş, H. \& A. Çağlar (2017), "Tabakalı İşgücü Piyasası Teorisine Göre Türkiye'de Özel-Hizmet Sektöründe İstihdamın Kalitesi”, İş, Güç Endüstri İlişkileri ve İnsan Kaynakları Dergisi, 19(1), 53-86.

Kumaş, H. et al. (2014), "Firm Size and Labour Market Segmentation Theory: Evidence from Turkish Micro Data", 10th International Strategic Management Conference, Procedia Social and Behavioral Sciences, (150), 360-373.

Lamotte, B. \& J.B. Zubiri-Rey (2008), "New Forms of Labour Market Segmentation, Insecurity and Professional Relations", The 29th Conference of the International Working Party on Labour Market Segmentation, Faculty of Economics University of Porto, 8-10 September, Porto.

Lazear, E.P. \& P. Oyer (2004), "Internal and External Labour Markets: A Personnel Economics Approach", Labour Economics, 11(5), 527-554.

Leontaridi, M. (1998), "Segmented Labour Markets: Theory and Evidence", Journal of Economic Surveys, 12(1), 63-101.

López-Roldán P. \& S. Fachelli (2020), "Measuring Labour Market Segmentation for a Comparative Analysis Among Countries", Social Indicators Research, 154, 857-892.

López-Roldán, P. et al. (2021), "Comparing Inequalities in the Labour Market from a Segmentation Perspective”, in: P. López-Roldán \& S. Fachelli (eds.), Towards a Comparative Analysis of Social Inequalities between Europe and Latin America (65-104), Switzerland: Springer. 
Loveridge, R. \& A. Mok (1980), “Theoretical Approaches to Segmented Labour Markets”, International Journal of Social Economics, 7(7), 376-411.

Lukac, M. et al. (2019), "Developing a Cross-National Comparative Framework for Studying Labour Market Segmentation: Measurement Equivalence with Latent Class Analysis", Social Indicators Research, 145, 233-255.

Marshall, A. (2013), Principles of Economics, England: Palgrave Macmillan.

McNabb, R. (1987), “Testing for Labour Segmentation in Britain”, The Manchester School, 55(3), 257-273.

Osterman, P. (1975), “An Empirical Study of Labour Market Segmentation”, Industrial and Labor Relations Review, 28(4), 508-523.

Pagés, C. \& M. Stampini (2009), "No Education, No Good Jobs? Evidence on the Relationship between Education and Labour Market Segmentation", Journal of Comparative Economics, 37(3), 387-401.

Piore, M.J. (1972), Notes for A Theory of Labour Market Stratification, <https://dspace.mit.edu/bitstream/handle/1721.1/64001/notesfortheoryof00pior.pdf?sequ ence=1\&isAllowed=y>, 14.03.2021.

Rebitzer, J.B. \& M.D. Robinson (1991), "Employer Size and Dual Labour Markets”, The Review of Economics and Statistics, 73(4), 710-715.

Reich, M. et al. (1973), "Dual Labour Markets: A Theory of Labour Market Segmentation", American Economic Review, 2, 359-365.

Şenel, D. (2021), “İnşaat Sektöründe Tabakalı İşgücü Piyasasının İncelenmesi: Denizli İli Örneği”, Ankara Üniversitesi SBF Dergisi, 76(1), 349-385.

Smith, A. (1997), Ulusların Zenginliği, (Çev. A. Yunus), İstanbul: Alan Yayıncılık.

Smith, D.R. \& E. Noma (1985), "Scaling Labour Markets: An Approach to Segmentation Research", Sociological Perspectives, 28(2), 145-173.

Stavik, T. \& T. Hammer (2020), Unemployment in a Segmented Labour Market? A Study of Youth Unemployment in Norway, NOVA - Norwegian Social Research, <https://fagarkivet.oslomet.no/bitstream/handle/20.500.12199/5138/4379_1.pdf?sequenc $\mathrm{e}=1$ \&isAllowed=y>, 07.12.2020.

Taubman, P. \& M.L. Watcher (1986), "Segmented Labour Markets", in: O.C. Ashenfelter \& R. Layard (eds.), Handbook of Labor Economics Vol. 1 (1183-1217), Amsterdam: Elsevier.

Wachter, M.L. (1974), "Primary and Secondary Labour Markets: A Critique of The Dual Approach", Brookings Papers on Economic Activity, 3, 637-693. 
Erdem-Karahanoğlu, G. \& H. Kumaş (2022), “Türkiye'de İyi ve Kötü İşler: Genç Çalışanlar Üzerinden Bir Analiz”, Sosyoekonomi, 30(51), 427-447. 